\title{
POLA PENINGKATAN KINERJA BISNIS UKM MELALUI MODAL SOSIAL DAN MODAL MANUSIA DENGAN KEBIJAKAN PEMERINTAH SEBAGAI MODERATING
}

\author{
Djoko Santoso \\ Program Studi Magister Manaajemen,Pascasarjana,Universitas Semarang \\ djoko_hw@usm.ac.id \\ Indarto \\ Program Studi Magister Manaajemen,Pascasarjana,Universitas Semarang \\ Indarto5758@gmail.com \\ Wyati Sadewisasi \\ Program Studi Magister Manaajemen,Pascasarjana,Universitas Semarang \\ wyatis@yahoo.com
}

\begin{abstract}
Abstrak
Penelitian ini untuk menjawabbagaimana meningkatkan kinerja bisnis UKM handy crab kota Semarangmelalui modal social dan modal manusia dengan moderating kebijakan pemerintah.

Populasi penelitian adalah para pengusaha UKM handy krab di kota Semarang. Dengan sampel 79 pengusaha yang tersebar di kota Semarang.. Analisis Moderating Regration dengan menggunakan moderating variable kebijakan pemerintah sebagai variable independen yang akan memperkuat atau memperlemah pengaruh antara modal social dan modal manusia terhadap kinerja bisnis UKM handy crab. Hasil penelitian menunjukkan bahwa modal social dan modal manusia berpengaruh positif dan signifikan dengan kinerja bisnis UKM handy crab. Kebijakan pemerintah mampu moderasi terhadap pengaruh modal social dan modal manusia terhadap kinerja bisnis UKM handy crab kota Semarang.
\end{abstract}

Kata Kunci: modal social, modal manusia, kebijakan pemerintah dan kinerja bisnis UKM handy crab.

\begin{abstract}
This research is to answer how to improve the business performance of Semarang City's handy crab SMEs through social capital and human capital by moderating government policies.

The research manipulation is handy krab SME entrepreneurs in the city of Semarang. With a sample of 79 entrepreneurs scattered in the city of Semarang. Moderating Regration Analysis using moderating government policy variables as an independent variable that will strengthen or weaken the influence between social capital and human capital on the business performance of handy crab SMEs.

The results showed that social capital and human capital had a positive and significant effect on the business performance of handy crab SMEs. Government policies are able to moderate the influence of social capital and human capital on the business performance of Semarang City's handy crab UKM.
\end{abstract}

Keywords: social capital, human capital, government policy and business performance of handy crab SMEs.

\section{PENDAHULUAN}

Usaha Mikro Kecil Menegah (UKM) bagian yang tidak bisa dilepaskan dalam kemajuan perekonomian suatu wilayah, termasuk perkembangan perekonomian di Kota Semarang sangat didukung dengan keberadaan UKM. Oleh karena itu, Pemerintah Kota Semarang berkomitmen memajukan UKM dengan menyediakan sarana prasarana, pembinaan usaha,pelatihan ketrampilan bagi tenaga kerja yang sesuai dengan amanat Undang Undang Nomor 20 Tahun 2008 tentang
UKM. Menurut Dinas Koperasi dan UKM Propinsi Jawa Tengah tahun 2017.perkembangan UKM di Jawa Tengah tahun 2016 sebanyak 115.751unit dan mampu menyerak 791.767 orang.Jumlah omset sebanyak 43,570 milyar dan asset sebanyak Rp.22.891 milyar. Sedangkan untuk Kota Semarang pada tahun 2016 untuk jumlah usaha mikro sebanyak 4.185 unit,pertumbuhan usahamikro sebesar 74,69 persen dan menyerap tenaga kerja sebanyak 6.936 orang, sedangkan omset penjualan sebanyak Rp 197.994 juta serta asset yang dimiliki sebanyakRp. 
42.638 juta (Dinas Koperasi dan UKM Kota Semarang,2017)

Ada temuan yang kontradiktif terhadap UKM pada saat ini, di satu sisi IMKM dianggap sebagai satu kekuatan ekonomi yang tangguh, khususnya pada masa krisis karena perannya. strategis dalam penyerapan tenaga kerja dan memberikan peluang kerja bagi masyarakat. Namun di sisi lainnya, ada fakta empiris UKM yang menunjukkan bahwa UKM belum memperlihatkan kinerja dan daya saing yang membaik, serta kualitas hidup yang lebih baik pada level mikro, khususnya pekerja dalam sektor ini (Manning dan Dierman, 2000; SMERU, 2000; Thee Kian We, 2004; World Economic Forum, 2004; Menperindag, 2005; ILO, 2010; Media Industri, 2011). Penelitian Stam dan Elfring (2008) memfokuskan peran jejaring intra dan ekstra industri sebagai salah satu unsur pembentuk modal social. Penelitian ini membuktikan bahwa modal sosial merupakan media mediasi yang memperkuat hubungan antara orientasi entrepreneur dengan kinerja. Nahapiet dan Goshal (1998) menyatakan bahwa indikator untuk modal sosial yaitu dimensi struktural, relasional dan kognitif.

Hasil penelitian Wahyuningrum (2013) memperlihatkan bahwa modal insani dan modal sosial memiliki pengaruh langsung terhadap kinerja pada UKM Kerajinan di Depok. Namun hasil penelitian tentang pengaruh modal sosial terhadap kinerja menunjukkan hasil yang berbeda-beda. Seperti pada penelitian Prasetyo (2013) yang menunjukkan bahwa beberapa indikator modal sosial tidak memiliki hubungan dengan kinerja bisnis pengusaha mikro dan kecil di Jawa Timur. Penelitian Hartono (2013) juga menunjukkan bahwa modal sosial tidak berpengaruh terhadap kinerja. Senada dengan Hartono, penelitian Winarni (2011) menunjukkan keterkaitan yang lemah antara modal sosial dan kinerja. Sedangkan penelitian khoirrini (2014) menunjukkan bahwa modal sosial berpengaruh positif terhadap kinerja UKM di Kota Bogor. Dan penelitian Andriani (2010) juga menunjukkan bahwa modal sosial dapat meningkatkan kinerja.

Berdasarkan temuan yang kontradiksi dalam upaya pencapaian kinerja usaha UKM, maka sangat diperlukan Human Capital (Modal Manusia). Modal manusia merupakan salah satu komponen utama dari intellectual capital sebagai intangible asset yang dimiliki oleh perusahaan. Selama ini penilaian terhadap kinerja perusahaan lebih banyak menggunakan sumber daya yang bersifat fisik (tangible asset) Menurut Mayo (2000) mengukur kinerja pe- rusahaan dari perspektif keuangan sangatlah akurat tetapi sebenarnya yang menjadi dasar penggerak nilai dari keuangan tersebut adalah sumber daya manusia (human capital) dengan segala pengetahuan, ide, dan inovasi yang dimilikinya. Selain itu, human capital merupakan inti dari suatu perusahaan.

Penyebutan human capital untuk sumber daya manusia (SDM) sepertinya belum banyak dianut oleh kalangan pelaku bisnis, padahal peran SDM terhadap masa depan perusahaan sangat menentukan. SDM adalah capital yang dapat terus berkem- bang seiring dengan waktu dan dinamika lingkungan bisnis serta kemajuan dalam ilmu pengetahuan. Keunggulan SDM dibanding faktor produksi lainnya dalam strategi bersaing suatu perusahaan antara lain meliputi: kemampuan inovasi dan entrepreneurship, kualitas yang unik, keahliaan yang khusus, pelayanan yang berbeda dan kemampuan produktivitas yang dapat dikembangkan sesuai kebutuhan (Mathis,2003).

Menurut Mayo (2000), sumber daya manusia atau human capital memiliki lima komponen yaitu individual capability, individual motivation, leadership, the organizational climate, dan workgroup effectiveness. Masing-masing komponen memiliki peranan yang berbeda dalam menciptakan human capital perusahaan yang pada akhirnya menentukan nilai sebuah perusahaan.

Disamping modal manusia, ternyata Modal Sosial memiliki peranan yang sangat penting dalam meningkatkan kinerja bisnis. Menurut Pratisthita et al. (2014) Modal Sosial merupakan nilai-nilai, norma dan trust (rasa saling mempercayai) dalam suatu masyarakat dimana masyarakat saling berpartisipasidan terdapat proses timbal balik di dalamnya. Modal Sosial mempererat hubungan keluarga dan memudahkan interaksi sosial. Hal ini dikarenakan anggota keluarga memiliki komitmen yang besar bagi perusahaan. Dengan demikian hubungan antar anggota keluarga merupakan sumber daya yang dapat digunakan untuk memaksimalkan kinerja perusahaan (Sanchez-Famoso et al., 2015). Modal Sosial memiliki tiga dimensi yakni dimensi struktural, dimensi relasional, dan dimensi kognitif menurut teori dari Nahapiet dan Ghoshal (1998) (dalam Abbasi et al., 2014). Dimensi struktural Modal Sosial terdiri dari tiga elemen yakni, jumlah relasi yang dimiliki, keberagaman relasi, dan jabatan atau kekuatan relasi yang dimiliki (Oliveira, 2013). Sedangkan inti dari dimensi relasional menurut Oliveira (2013) adalah kepercayaan, relasi dapat diandalkan, tanggung jawab, dan feedback yang didapat, dan elemen-elemen yang terdapat dalam dimensi kognitif meliputi norma-norma 
kebersamaan, kode tindakan, dan kesamaan pandangan(Abbasi et al., 2014)

Modal social baik yang bersumber dari sumber internal maupun eksternal organisasi, samasama memiliki peran positif dalam meningkatkan efektifitas organisasi. Pernyataan tersebut didukung oleh hasil penelitian Leana \& Frits (2006) pada sekolah-sekolah di Amerika. Hasil penelitian mereka menunjukkan bahwa modal sosial baik internal maupun eksternal memiliki efek positif pada kinerja organisasi.

Strategi pembangunan ekonomi wilayah khususnya UKM perlu memperhatikan peran intervensi pemerintah (kebijakan pemerintah) dan dinamika kehidupan masyarakat lokal menyangkut sumber daya sosial (modal sosial), modal manusia selain modal fisik. Menurut Diva (2009), peran pemerintah dalam pembangunan UKM (termasuk industri hendi crab) yang efektif dan optimal diwujudkan sebagai: (1) fasilitator dalam pelatihan kewirausahaan, (2) katalisator dalam pemberdayaan dan pemodalan komunitas kreatif (termasuk industri tenun), dan (3) regulator dalam kebijakan yang mempermudah berkembangnya kreatifitas berusaha dan berinvestasi.Sedangkan aktivitas wirausaha modern mengacu pada konsep kewirausahaan dan kinerja usaha diukur dalam empat indikator, yakni: peningkatan jumlah produksi, (2) peningkatan jenis unit usaha, (3) peningkatan volume penjualan, dan (4) peningkatan laba usaha (Suci, 2009). Peran intervensi pemerintah telah menjadi fenomena umum dalam pembangunan ekonomi terutama di negara- negara berkembang. Intervensi yang melebihi kapasitas ternyata telah mendorong terjadinya distorsi ekonomi.Satu pihak menginginkan pemerintah tidak perlu campur tangan dalam mengelola atau mengurus suatu perekonomian, cukup pihak swasta atau para pengusaha saja. Dilain pihak justru masyarakat atau pengusaha sendiri (kalangan industri ) justru tidak menginginkan pemerintah lepas tangan dalam menangani suatu persoalan ekonomi, mungkin karena takut menanggung resiko yang terlalu besar atau malah tidak dapat dipercaya pihak swasta oleh masyarakat tersebut.

\section{TELAAH PUSTAKA}

\subsection{Kinerja Bisnis.}

Sebuah organisasi bisnis dapat mengukur kinerjanya dengan menggunakan ukuran financial atau disebut kinerja keuangan dengan menggunakan perolehan laba dan volume penjualan (Chong, 2008) Prosedur pengukuran kinerja usaha Kecil Menengah
(UKM) dapat dilakukan dengan penilaian terhadap persepsi responden (Lechner dan Gudmundsson, 2014) berdasarkan atas beberapa ukuran finansial, seperti tingkat penjualan, pertumbuhan penjualan, keuntungan kotor, rasio keuntungan atas penjualan, tingkat pengembalian modal, dan laba bersih operasi. Dengan demikian, pengukuran terhadap kinerja usaha akan sangat tergantung kepada seberapa valid ukuran-ukuran tersebut sesuai dengan kinerja yang dicapai oleh perusahaan. Pengukuran kinerja bisnis dapat dilakukan melalui beberapa aspek berikut, yaitu kinerja keuangan, kinerja operasional, kinerja pemasaran, dan kinerja sumber daya manusia.

Menurut Suci (2009) kinerja usaha memiliki indicator peningkatan produksi,pengembangan unit bisnis,peningkatan volume penjualan dan peningkatan keuntungan.

Armstrong (2004) dalam teorinya merumuskan bahwa kinerja merupakan sebuah hasil pekerjaan yang mempunyai hubungan kuat dengan tujuan strategis organisasi, kepuasan konsumen dan memberikan kontribusi ekonomi. Kondisi kinerja dapat berlaku pada perorangan maupun organisasi seperti yang diungkapkan oleh Rivai (2008) yang menyatakan "Kinerja merupakan hasil atau tingkat keberhasilan seseorang secara keseluruhan selama periode tertentu di dalam melaksanakan tugas dibandingkan dengan berbagai kemungkinan, seperti standar hasil kerja, target atau sasaran atau kriteria yang telah ditentukan terlebih dahulu dan telah disepakati bersama".

Menurut Ghifary,(2013) kinerja adalah hasil kerja yang dicapai oleh seseorang atau kelompok dalam organisasi, sesuai dengan wewenang dan tanggung jawab, dalam upaya untuk mencapai tujuan organisasi secara legal, tidak melanggar hukum, dan sesuai dengan moral dan etika . Kinerja bisnis merupakan akumulasi dari hasil aktivitas yang dilakukan dalam perusahaan itu sendiri (Prasetyo \& Harjanti, 2013). Dalam penelitian ini, kinerja perusahan dibagi menjadi 3 indikator sesuai teori Turner, (2011) yaitu inovasi perusahaan, profitabilitas, dan outcomes of cost improvem

\subsection{Modal Sosial}

Bourdieu (1986) menyatakan bahwa, volume social capital yang dimiliki oleh seseorang tergantung pada ukuran jejaring koneksi yang dapat dimobilisasikannya serta pada volume modal (ekonomi, budaya, atau simbolis) yang dimilikinya. Ini artinya bahwa, meski relatif tidak dapat direduksi ke modal ekonomi dan budaya yang dimiliki oleh agen tertentu, atau bahkan oleh seluruh agen yang terhubung, social capital tidak pernah independen 
seluruhnya dari agen karena pertukaran-pertukaran membentuk pengenalan satu sama lain.

Bourdieu $(1980 ; 1986)$, hubungan yang erat dan tahan lamanya adalah ikatan yang sama vitalnya: social capital merepresentasikan agregate sumber daya aktual atau potensi yang dikaitkan dengan kepemilikan jaringan yang tahan lama, nilai ikatan yang dijalin seorang individu (atau volume social capital yang dimiliki agen tertentu tergantung pada jumlah koneksi yang dapat mereka mobilisasi dan volume modal (budaya, sosial dan ekonomi) yang dimiliki masing-masing koneksi. Dalam mempertahankan pandangan tentang modal sebagai produk akumulasi kerja. Bourdieu menegaskan bahwa koneksi memerlukan kerja. Solidaritas dalam jaringan hanya mungkin terjadi karena keanggotaan di dalamnya meningkatkan laba, baik laba material maupun laba simbolik.

Dengan demikian, mempertahankan hal tersebut diperlukan "strategi investasi secara individu maupun kolektif" yang bertujuan mentrasformasikan hubungan-hubungan yang terus berlangsung, seperti hubungan di kampung atau tempat kerja, atau hubungan keke-rabatan, menjadi "hubungan sosial yang secara langsung dapat diguna-kan dalam jangka pendek atau jangka panjang"; karena hal itu hanya efektif dalam jangka panjang yang dirasakan secara subjektif (Bourdieu,1980;1986), misalnya pertukaran hadiah: "upaya untuk mempersonalisasikan hadiah" mengubah nilai yang sepenuhnya bersifat moneter dan juga titik temu pada skala yang lebih luas, sehingga menjadi "investasi solid, yang labanya akan muncul dalam jangka panjang dalam bentuk uang dan bentuk lainnya", dengan investasi yang berbentuk "upaya sosiabilitas tiada henti" (Bourdieu, 1986).

Sementara, Putnam (1993): "social capital refers to features of social organizations, such as trust, norms, and networks", bahwa social capital didefinisikan sebagai rasa percaya, norma timbal-balik dan jaringan sosial. Atribut ini yang memungkinkan para partisipan bertindak bersama secara lebih efektif untuk mencapai tujuan bersama (Prasetiamartati et al., 2016).

Social capital yang kuat akan meningkatkan keefektifan suatu kelompok dalam mencapai tujuan dan mengurangi tekanan didalam kelompok karena setiap anggota merasa nyaman berada di dalam kelompoknya (Pratisthita et al., 2014).

Modal sosial disusun menjadi dimensi struktural, dimensi relasional, dan dimensi kognitif (Hauetal, 2013; He etal., 2009, Chow dan Chan,
2008). Dimensi struktural merupakan pola hubungan antar orang dan interaksi sosial yang ada dalam organisasi. Dimensi relasional merupakan asset yang diciptakan dan tumbuh dalam hubungan antar anggota organisasi yang mencakup kepercayaan (trust) dan kelayakan dipercaya (trust worthiness). Kepercayaan adalah atribut yang melekat dalam suatu hubungan. Kelayakan dipercaya merupakan atribut yang melekat pada individu yang terlibat dalam hubungan tersebut. Dimensi kognitif merupakan sumberdaya yang memberikan representasi dan interpretasi bersama, serta menjadi sistem makna (system of meaning) antar pihak dalam organisasi. Nahapiet dan Ghoshal (1998) mendefinisikan dimensi ketiga ini sebagai shared languages (codes), shared narratives dan shared vision yang memfasilitasi pemahaman tentang tujuan kolektif dan cara bertindak dalam suatu sistem sosial. Shared language (codes) akan tampak pada penggunaan kata-kata tertentu sebagai kata-kata (istilah-istilah) yang dipahami bersama dalam komunikasi antar anggota organisasi. Sharednarratives akan tampak jika anggota organisasi seringkali menceritakan hal-hal yang sama dalam bentuk bentuk "mitos organisasi" ataupun tentang hal-hal yang terjadi dalam kehidupan kerja mereka. Sharedvision akan tampak jika anggota organisasi memiliki pemahaman yang sama tentang apa yang ingin dicapai organisasi Stametal. (2013) yang meneliti modal sosial pada UKM. Mereka fokus pada analisis tingkat individu sebagai entrepreneur. Dibandingkan dengan eksekutif di perusahaan besar, pengusaha (entrepreneur) di perusahaan kecil lebih terlibat secara langsung dalam operasi perusahaan seharihari, memiliki kewenangan yang lebih besar dalam pengambilan keputusan, dan lebih sering melakukan peran kunci (Hite dan Hesterly, 2001). Modal sosial tingkat individu yang tertanam dalam jaringan pribadi pengusaha dapat mempengaruhi kinerja UKM. Stam W, Elfring T.(2008) menyimpulkan hasil kajiannya menunjukkan modal sosial merupakan media mediasi yang memperkuat hubungan antara orientasi entrepreneur dengan kinerja

\subsection{Modal Manusia}

Modal manusia wujud di dalam diri manusia pekerja, apabila manusia yang membentuk organisasi semakin mendapatkan pengakuan atas kontribusi dan pentingnya mereka terhadap keberhasilan organisasi. Bahkan modal manusia tersebutlah yang menjadikan pekerja sebagai satu sumberdaya yang unik untuk organisasi. Menurut 
Carmeli \& Tishler 2004a) . Keunikan tersebut telah menjadikan modal manusia sebagai sumber efisiensi dan efektivitas organisasi, dan dianggap juga sebagai sumberdaya strategis organisasi

Bontis dan Serenko (2009) berpendapat, modal manusia meliputi tiga faktor, yaitu kompetensi, pengalaman dan pengetahuan yang dimiliki oleh seorang individu. Bagi Hitt, Bieman, Shimizu dan KLochhar (2001) dalam studi mereka mencatat bahwa modal manusia memiliki dua dimensi, yaitu kualitas dan pengalaman. Sedangkan Wright, McMahan dan McWilliams (1994) menjelaskan bahwa modal manusia melibatkan dimensi seperti pengalaman, penilaian dan kecerdasan.

Meskipun demikian, penelitian ini mencoba melihat modal manusia melalui dimensi kompetensi, pendidikan dan pengalaman kerja. Tiga dimensi modal manusia ini telah digunakan oleh Aryee, Chay dan Tan (1994), Carmeli dan Tishler (2004a), Carmeli dan Tishler (2004b) dan Castro dan Saez (2008). Dimensi-dimensinya cocok untuk diterapkan karena terbukti sesuai digunakan di berbagai lingkungan organisasi, misalnya di lingkungan organisasi publik seperti yang dilakukan oleh Carmeli dan Tishler (2004a), dan di lingkungan organisasi swasta seperti kajian Castro dan Saez (2008) dan Carmeli dan Tishler (2004b). Selain itu, telah digunakan pula dalam penelitian Carmeli dan Tishler (2004b) yang melibatkan perusahaan-perusahaan dari industri dan ukuran organisasi yang berbeda-beda.

Modal manusia diukur dengan dimensi kompetensi, pendidikan dan pengalaman kerja. Instrumen untuk dimensi-dimensi tersebut diperoleh dari Carmeli dan Tishler. Mereka telah mengambil item-item Pernyataan dari Aryee et al. (1994). Instrumen ini digunakan oleh Castro dan Saez (2008) di mana terdapat empat item untuk pendidikan dan pengalaman kerja dan empat item untuk kompetensi.

Murphy dan Poist (1993) juga menyatakan pandangan bahwa kepentingan karyawan menjadi lebih tinggi jika operasi masih padat karya. Mereka menyimpulkan bahwa jika pergudangan ingin meningkatkan efisiensi, maka fokus tumpuan perlu diberikan kepada karyawan. Pandangan Murphy dan Poist (1993) ini turut disetujui oleh Kelley dan Hounsell. Bahkan, karyawan juga ikut dikaitkan dengan kinerja perusahaan dari sudut kualiti. Wahyuningrum (2013) modal insani dan modal sosial memiliki pengaruh langsung terhadap kinerja pada UKM Kerajinan di Depok.

\subsection{Kebijakan Pemerintah.}

Munir (2010) menjelaskan peran pemerinta meliputin (a). Enterpreneur Artinya pemerintah daerah bertanggung jawab untuk melaksanakan usaha dalam mengelola sumber daya ekonomi, mengelola aset-aset daerah sumber daya ekonomi potensial, sehingga secara ekonomi menguntungkan dan memberi manfaat bagi masyarakat. (b). Koordinator Sebagai koordinator pemerintah daerah dapat menetapkan kebijaksanaan atau strategi bagi pembangunan daerah dan merangkul semua komponen masyarakat untuk menjadi aktor dalam pembangunan. (c). Fasilitator Sebagai fasilitator pemerintah daerah dapat mempercepat pembangunan melalui perbaikan lingkungan attitudional, yaitu berkaitan dengan perbaikan prosedur perijinan dan pelayanan, serta melakukan penetapan daerah untuk memantapkan pengaturan dimensi spasial dalam pembangunan.

Kemudian, Siagian

mengklasifikasikan peran dan fungsi pemerintah sebagai berikut: (a). Fungsi pemeliharaan ketertiban dan ketenangan (Maintenance of peace and order) Fungsi ini merupakan fungsi yang sangat penting oleh karena ketertiban dan ketenangan dalam pembangunan tidak akan ada apabila pemerintah tidak berhasil dalam melakukan fungsi ini. Gangguan tersebut dapat terjadi dari mana saja. (b). Fungsi pertahanan dan keamanan Fungsi ini merupakan fungsi terpenting pula dari pemerintah karena tidak jarang terlihat adanya keinginan dari pihak-pihak tertentu untuk mendominasi pihak lain dengan tujuan agar pihak lain itu dapat dipergunakan sebagai alat untuk meningkatkan kemakmuran pihak-pihak yang lebih kuat. (c). Fungsi Perpajakan Fungsi ini merupakan salah satu fungsi pemerintah yang pertama timbul di negara politik, tujuannya adala bahwa untuk menjalankan kegiatan-kegiatan pemerintah, pemerintah selalu membutuhkan biaya dan biaya itu secara tradisionil bersumber dari pajak. (d) Fungsi Hukum Tujuan dari fungsi ini adalah untuk mengatur tata benegara dan tata bermasyarakat agar konflik-konflik yang terjadi dalam pembangungan dapat diselesaikan menurut kriteria yang telah diakui dan diterima oleh masyarakat, karena mereka penguasa dan masyarakat akan berkedudukan sama dimata hukum. (e) Fungsi Administratif Dalam fungsi ini pemerintah harus bekerja demi kepentingan dan kesejahteraan rakyat dan bukan untuk kepentingan sekolompok orang yang dapat menghambat kesejahteraan masyarakat. Pemerintah harus harus berusaha melaui pelaksanaan-pelaksanaan kegiatan, tugas-tugas, wewenang dan tanggung jawabnya 
meningkatkan taraf hidup orang banyak dalam pembangunan tersebut. G.K.Gandhiadi,Komang Darmawan,I Putu Eka Nila Kencana (2018) menyimpulkan hasil penelitiannya, Peran pemerintah berpengaruh positif dan signifikan terhadap kinerja usaha pelaku usaha industri tenun di Kabupaten Jembrana. Layla Khoirrini dan Lindawati Kartika (2014) menyimpulkan hasil penelitiannya modal insani dan modal sosial berpengaruh positif dan signifikan terhadap kinerja.

\subsection{Kerangka Pemikiran Teoritis}

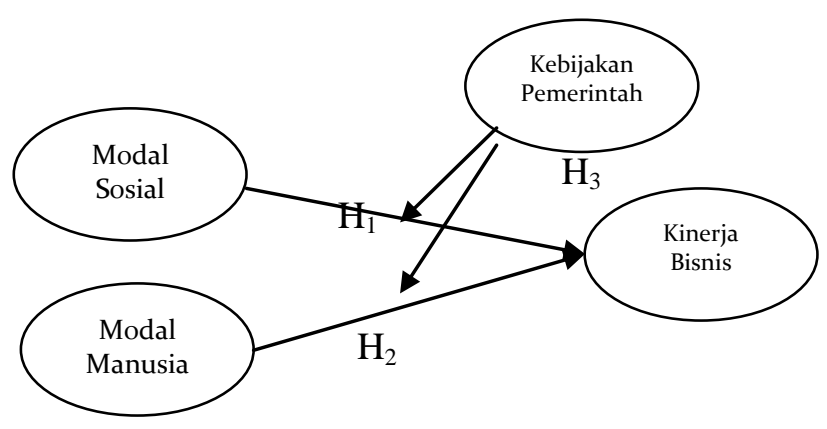

\subsection{Populasi dan Sampel.}

a. Populasi

Ferdinad ( 2006) dalam Rahmad dan Herjanto (2012) menjelaskan populasi adalah gabungan dari seluruhelemen yang berbentuk peristiwa atau orang yang memliki karakteristik yang serupa yang menjadi pusat perhatian peneliti. Dikarenakan penulis tidak mengetahui jumlah populasi secara pasti yaitu populasi pengusaha UKM Handy Crab di kota Semarang.

b. Sampel.
Sugiyanto,2011 ( dalam Rahmad \& Heryanto,2012) menjelaskan, sampel adalah bagian dari populasi yang ada, sehingga untuk pengambilan sampel harus menggunakan cara tertentu didasarkan oleh beberapa pertimbangan yang ada.Sampel dalam penelitian ini adalah pengusaha UKM hendy crab . Dikarenakan peneliti tidak mengetahui secara pasti jumlah populasi secara pasti yaitu pengusaha UKM Hendy Crab di Kota Semarang. Maka jumlah sampel dalam penelitian ini disamakan dengan kelayakan secara statistic yaitu sebanyak 79 responden yang tersebar di kota Semarang.

\section{METODE PENGUMPULAN DATA}

\subsection{Skala Pengukuran.}

Alat pengukuran yang akan digunakan dalam penelitian ini menggunakan pengukuran dan interval. Skala interval adalah alat pengukuran data yang dapat menghasilkan data yang memiliki rentang nilaiyang mempunyai makna, walaupun nilai absolutnya kurang bermakna. Skala ini menghasilkan pengukuranyang memungkinkan perhitungan rata-rata, deviasi standart, statistic parameter, korelasi dan sebagainya.Data yang berbentuk interval dapat dihasilkan dengan suatu teknik, yaitu hipolat affective. Skala pengukuran dengan menggunakan Likerd skala $1 \mathrm{~s} / \mathrm{d} 5$, di mana 1 sangat tidak setuju, 2 tidak setuju, 3 .cukup setuju, 4. Setuju, dan 5 sangat setuju.

\subsection{Pelaksanaan Pengumpulan Data}

Pengumpulan data menggunakan teknik survey dengan kuesioner yang dilakukan pleh surveyor/enumerator. Untuk menyakinkan bahwa kuesioner yang dikirim telah diterima maka dilakukan pengecekan memalui telpon.

\subsection{Definisi Operasional dan Indikator}

Tabel 3.1

Variabel dan Indikator Variabel Penelitian Model Empiris

\begin{tabular}{|c|c|c|c|}
\hline Variabel & Definisi & Indikator & Sumber \\
\hline Modal sosial & $\begin{array}{l}\text { rasa percaya, norma timbal-balik } \\
\text { dan jaringan sosial. Atribut ini yang } \\
\text { memungkinkan para partisipan } \\
\text { bertindak bersama secara lebih } \\
\text { efektif untuk mencapai tujuan } \\
\text { bersama }\end{array}$ & $\begin{array}{l}\text { X1.1 = Dapat Dipercaya } \\
\text { X1.2 = Memiliki } \\
\text { hubungan baik sesama } \\
\text { pengusaha } \\
\text { X13 = Kerjasama dalam } \\
\text { melakuka usaha } \\
\text { X1.4= Memiliki jaringan } \\
\text { bisnis } \\
\text { X1.5=Mengutaamakan } \\
\text { kepentingan } \\
\text { umum/pelanggan }\end{array}$ & $\begin{array}{l}\text { Grootaert (1999), } \\
\text { Fukuyama (1999) } \\
\text { Salman (2007) }\end{array}$ \\
\hline Modal Manusia & $\begin{array}{lrr}\text { modal manusia } & \text { meliputi tiga } \\
\text { faktor, yaitu } & \text { kompetensi, } \\
\text { pengalaman dan } & \text { pengetahuan }\end{array}$ & $\begin{array}{l}\text { X2.1=Pendidikan } \\
\text { berperan penting untuk } \\
\text { usaha }\end{array}$ & $\begin{array}{l}\text { Bontis dan Serenko } \\
(2009) \\
\text { Becker }\end{array}$ \\
\hline
\end{tabular}




\begin{tabular}{|c|c|c|c|}
\hline Variabel & Definisi & Indikator & Sumber \\
\hline & yang dimiliki oleh seorang individu & $\begin{array}{l}\text { X2.2=Ketrampilan } \\
\text { memudahkan usaha } \\
\text { X2.3= Pengalaman } \\
\text { mendukung usaha } \\
\text { X2.4= Pelatihan } \\
\text { membantu } \\
\text { pengembangan } \\
\text { X2.5.Memanfaatkan } \\
\text { teknologi untuk } \\
\text { menciptakan keunggulan }\end{array}$ & \\
\hline $\begin{array}{l}\text { Kebijakan } \\
\text { Pemerintah }\end{array}$ & $\begin{array}{l}\text { Intervensi kebijakan pemerintah } \\
\text { adalah cara atau langkah yang } \\
\text { dilakukan agar sebuah kebijakan } \\
\text { dapat mencapai tujuannya }\end{array}$ & $\begin{array}{l}\text { Z3.1=Fasilitator } \\
\text { pemerintah mendukung } \\
\text { usaha } \\
\text { Z3.2=Program } \\
\text { pemerintah mendukung } \\
\text { bisnis } \\
\text { Z3.3 =Tingkat suku } \\
\text { bunga kredit meendukung } \\
\text { usaha. } \\
\text { Z3.4 = Pembinaan } \\
\text { pemerintah mendukung } \\
\text { usaha } \\
\text { Z3.5= Peraturan UKM } \\
\text { melindungi bisnis }\end{array}$ & $\begin{array}{l}\text { Diva (2009) Mazmanian } \\
\text { dan Sabatier (1983) }\end{array}$ \\
\hline Kinerja Bisnis & $\begin{array}{lr}\text { kinerja usaha memiliki } & \text { indicator } \\
\text { peningkatan } & \\
\text { produksi,pengembangan } & \text { unit } \\
\text { bisnis,peningkatan } & \text { volume } \\
\text { penjualan dan peningkatan } \\
\text { keuntungan. }\end{array}$ & $\begin{array}{l}\text { Y1=Peningkatan } \\
\text { pendapatan } \\
\text { Y2=Jumlah pelanggan } \\
\text { meningkat. } \\
\text { Y3= Keberhasilan dalam } \\
\text { pencapaian target } \\
\text { Y4= Aktivitas yang tinggi } \\
\text { para pengusaha } \\
\text { mendukung keberhasilan. } \\
\text { Y5 = Peningkatan } \\
\text { penjualan }\end{array}$ & Suci (2009) \\
\hline
\end{tabular}

\subsection{Uji Validasi Dan Reliabilitas}

\section{Uji Validitas}

Uji validitas digunakan untuk mengukur sah atau valid tidaknya suatu kuisioner. Suatu kuisioner dikatakan valid jika Pernyataan pada kuisioner mampu untuk mengungkapkan sesuatu yang akan diukur oleh kuisioner tersebut Ghozali, (2002). Untuk menguji valid tidaknya Pernyataan tersebut maka penulis akan menggunakan program SPSS dengan tingkat kepercayaan $95 \%(\alpha=0,05)$.

\section{Uji Reliabilitas}

Uji reliabilitas merupakan uji kehandalan yang bertujuan untuk mengetahui seberapa jauh suatu alat ukur dapat dipercaya. Kehandalan berkaitan dengan estimasi sejauh mana suatu alat ukur konsisten apabila pengukuran dilakukan berulang dan hasil pengukuran yang diperoleh relatif konsisten maka alat ukur tersebut dianggap handal (reliabel). Sebaliknya, bila suatu alat ukur digunakan berulang dan hasil pengukuran yang diperoleh tidak konsisten dengan hasil sebelumnya maka alat ukur tersebut dianggap tidak reliabel.

Uji reliabilitas dilakukan dengan menggunakan koefisien alpha.Kalkulasi koefisien alpha memanfaatkan bantuan SPSS dan batas kritis untuk nilai alpha untuk mengindikasikan kuesioner yang reliabel adalah 0.60 . Jadi nilai koefisien alpha > 0.60 merupakan indikator bahwa kuesioner tersebut reliabel atau handal.

\section{Metode analisis data}

Metode analisis data yang dimaksud untuk membahas dan menjabarkan data yang diperoleh. Kemudian masalah yang ada disimpulkan agar didapatkan jawaban yang tepat. Dalam penelitian ini metode analisis data yang digunakan adalah sebagai berikut ini. 


\section{Analisis Deskriptif}

Analisis diskriptif adalah analisis yang digunakan untuk menganalisis data dengan cara mendiskripsikan atau menggambarkan data yang telah terkumpul sebagaimana adanya tanpa bermaksud membuat kesimpulan yang berlaku. Jadi analisis diskriptif ini hanya digunakan untuk mendiskripsikan data sample. Dalam analisis diskriptif ini penyajian data melalui tabel dan perhitungan rata-rata.

\section{Analisis Kuantitati}

Analisis yang digunakan adalah uji validitas, uji reliabilitas, moderating regression analisis dalam melakukan perhitungan tersebut penulis menggunakan analisis statistik. Untuk membantu mengolah data Yaitu suatu analisis untuk mengetahui seberapa besar pengaruh variabel independen terhadap variabel dependen, Sudjana (2006).

\section{Uji Asumsi Klasik}

Dalam melakukan estimasi model regresi, terdapat asumsi-asumsi dasar yang tidak boleh dilanggar agar hasil estimasinya dapat digunakan sebagai dasar analisis. Ada tiga masalah yang seringkali muncul yang dapat mengakibatkan tidak terpenuhinya asumsi dasar (klasik), yaitu normalitas, multikolinieritas, heteroskedasitas dan korelasi serial. Dalam penelitian ini akan dilakukan uji terhadap ada tidaknya gangguan normalitas, multikolinieritas, heteroskedasitas dan korelasi serial.

\section{Uji Asumsi Normalitas}

Uji normalitas untuk mengetahui apakah populasi data berdistribusi normal atau tidak. Uji normalitas sampel dimaksudkan untuk menguji normal tidaknya sampel. Pengujian diadakan dengan maksud untuk melihat normal tidaknya data yang akan dianalisis. Dalam penelitian ini menggunakan teknik uji parametrik kolmogorovsmirnov.

\section{Uji Heteroskedasitas}

Pengujian ini dilakukan untuk menunjukkan bahwa varians dari setiap error bersifat heterogen yang berarti melanggar asumsi klasik yang mensyaratkan bahwa varians error harus bersifat homogen. Langkah-langkah dalam pengujian heteroskedastisitas adalah sebagai berikut:

Ho : Tidak ada heteroskedastisitas

Ha : Ada heteroskedastisitas

\section{Uji Multikolinieritas}

Multikolinieritas dilakukan untuk menunjukkan bahwa antara variable independen mempunyai hubungan langsung (berkorelasi). Konsekuensi dari multikolinieritas akan menyebabkan kuesioner regresi nilainya kecil, apabila standar error regresi nilainya besar maka pengujian individunya tidak signifikan. Ciri adanya multikolinieritas adalah R2 tinggi, F-test signifikan namun t-testnya banyak yang tidak signifikan.

\section{Analisis Regresi Moderasi.}

Analisis Regresi dengan Moderasi dengan menggunakan variable moderating.Variabel ,oderating adalah variable independent yang akan memperkuat atau memperlemah hubungan antara variable independen lainnya terhadap variable dependen. Dalam hal ini dapat dibuat persamaan sebagai berikut:

$\mathrm{Y}=\beta 1 \mathrm{X} 1+\beta 2 \mathrm{X} 2+\mathrm{e} \ldots \ldots \ldots .$. Persamaan. 1 .

$Y=\beta_{1} X_{1}+\beta 2 X_{2}+\beta_{3}\left(Z * X_{1} * X_{2}\right)+$ e...,,Persamaan 2

Keterangan:

$\beta_{1-2}=$ Koefisien Regresi, $e_{1-2}=$ Tingkat kesalahan penduga dalam penelitian, $\mathrm{Y}=$ Kinerja Bisnis $\mathrm{UKM}, \mathrm{X} 1=$ Modal Sosial, $\mathrm{X} 2=$ Modal Manusia, Z= Kebijakan Pemerintah

\section{Uji Hipotesis}

Uji hipotesis adalah metode pengambilan keputusan yang didasarkan dari analisis data, baik dari percobaan yang terkontrol, maupun dari observasi (tidak terkontrol). Dalam statistik sebuah hasil bisa dikatakan signifikan secara statistik jika kejadian tersebut hampir tidak mungkin disebabkan oleh faktor yang kebetulan, sesuai dengan batas probabilitas yang sudah ditentukan sebelumnya. Uji hipotesis kadang disebut juga "konfirmasi analisis data". Keputusan dari uji hipotesis hampir selalu dibuat berdasarkan pengujian hipotesis nol. Ini adalah pengujian untuk menjawab Pernyataan yang mengasumsikan hipotesis nol adalah benar.

\section{Koefisien determinasi}

Koefisien determinasi (R2) pada intinya mengukur seberapa jauh kemampuan dalam menerangkan variasi variabel dependen. Nilai koefisien determinasi diantara nol dan satu. Nilai $\mathrm{R}^{2}$ yang kecil berarti kemampuan variabel-variabel independen dalam menjelaskan variabel dependen amat terbatas. 


\section{HASIL DAN PEMBAHASAN. Identitas Responden \\ Jenis Kelamin}

Dari penelitian terhadap 79 orang responden yang diteliti, jenis kelamin responden dapat ditunjukkan dalam tabel berikut :

Tabel 4.1 Distribusi Responden menurut Jenis Kelamin

\begin{tabular}{|c|c|c|}
\hline Jenis Kelamin & Frekuensi (Orang) & Persentase \\
\hline Laki-laki & 34 & $43.04 \%$ \\
Wanita & 45 & $56.96 \%$ \\
\hline Jumlah & 79 & $100 \%$ \\
\hline
\end{tabular}

Sumber : Data Primer yang diolah, 2019

Dari tabel 4.1.dapat diketahui bahwa dari penelitian terhadap 79 orang responden menunjukkan bahwa jumlah responden dengan jenis kelamin wanita sebanyak 45 orang atau $56.96 \%$ yang terpaut lebih sedikit daripada jumlah responden laki-laki sebanyak 34 orang atau $43.04 \%$. Hal ini dikarenakan didunia UKM Hendy Crab ternyata kegiatan ini dilakukan oleh ibu ibu yang banyak memiliki kreatifitas, selalu ingin belajar, kesabaran, ketlitian dan ketekunan yang berlebih sehingga menyebabkan jenis kelamin wanita lebih banyak yang tertarik menekunin dunia kerajinan tangan dibandingkan dengan jenis kelamin laki - laki.

\section{Usia Responden}

Dari penelitian terhadap 79 orang responden yang diteliti, kategori usia responden dapat ditunjukkan dalam tabel berikut :

Tabel 4.2

Distribusi Frekuensi Berdasarkan Usia

\begin{tabular}{|c|c|c|}
\hline Umur & $\begin{array}{c}\text { Frekuensi } \\
\text { (Orang) }\end{array}$ & $\begin{array}{c}\text { Persentas } \\
\mathrm{e}\end{array}$ \\
\hline 25 Tahun - 29 Tahun & 11 & $13.92 \%$ \\
30 Tahun - 34 Tahun & 14 & $17.72 \%$ \\
35 Tahun -40 Tahun & 31 & $39.24 \%$ \\
41 Tahun - 45 Tahun & 13 & $16.46 \%$ \\
46 Tahun - 50 Tahun & 10 & $12.66 \%$ \\
\hline Jumlah & 79 & $100 \%$ \\
\hline
\end{tabular}

Berdasarkan tabel 4.2 dapat dilihat bahwa responden terbesar berumur 35 tahun sampai dengan 40 tahun sebanyak 31 orang atau sebanyak $39.24 \%$. Hal ini menandakan bahwa pada umur tersebut di atas merupakan usia yang cukup matang dan berpengalaman bagi UMKM kerajinan tangan kota Semarang

\section{Lama Usaha.}

Pada umumnya pengusaha handy crab atau kerajinan tangan sudah memiliki pengalaman yang cukup.Hal ini bias di lihat dalam table 4.3.

Tabel 4.3

Lama Usaha Handy Crab Kota Semarang

\begin{tabular}{|c|c|c|c|}
\hline No & Lama Usaha & $\begin{array}{c}\text { Frekuensi } \\
\text { (orang) }\end{array}$ & Presentase \\
\hline 1 & $3-5$ tahun & 25 & $31,64 \%$ \\
\hline 2 & $6-8$ tahun & 19 & $24,15 \%$ \\
\hline 3 & $9-11$ tahu & 20 & $25,30 \%$ \\
\hline 4 & $\begin{array}{l}\text { Lebih } 11 \\
\text { tahun }\end{array}$ & 15 & $18,91 \%$ \\
\hline & Jumlah & 79 & $100,00 \%$ \\
\hline
\end{tabular}

Sumber:Data primer yang diolah.2019

Dari table 4.3 menunjukkan bahwa pengusaha handy crab/ kerajinan tangan memiliki usaha 3-5 tahun sebanyak 25 orang $(31,64 \%)$ dan yang [a;ong lama lebih 11 tahun $(18,91 \%)$.Ini menunjukan keseriusan berusaha kerajinan tangan / handy crab bias dihandalkan untuk meningkatkan pendapatan keluarga.

\section{Asal Modal Awal Usaha.}

Para pengusaha UKM Hady Crab pada waktu memulai usaha memiliki variasi permodalan awal yang didapatkan untuk mulai usaha, Hal Ini dapat di lihat dari table 4.4 di bawah:

Tabel 4.4. Asal Mula Modal Awal pengusaha UKM Handy Crab

\begin{tabular}{|c|l|c|c|}
\hline No & \multicolumn{1}{|c|}{ Asal Modal Awal } & $\begin{array}{c}\text { Frekuensi } \\
\text { (Orang) }\end{array}$ & Prosentase (\%) \\
\hline 1 & Diri sendiri & 14 & 17,74 \\
\hline 2 & Pinjam saudara & 7 & $8,86 \%$ \\
\hline 3 & Orang Tua & 10 & $12,65 \%$ \\
\hline 4 & Pinjam Kredit Bank & 22 & 27,86 \\
\hline 5 & Pinjam Koperasi & 13 & 16,45 \\
\hline 6 & Lain lain: Menjual barang/aset & 13 & 16,45 \\
\hline \multicolumn{2}{|l|}{} & 79 & 100,00 \\
\hline
\end{tabular}


Pada umumnya para pengusaha Handy Crab/kerajinan tangan di Kota Semarang kebuthan modal awal sangat variasi untuk memenuhi kebutuhan modal, namun yang paling banyak kredit Bank/pinjam bank sebanyak 22 orang $(27,80)$ karena dapat pinjaman lebih banyak dan yakin mampu mnemebalikan dengan adanya berbagai promosi dengan bunga yang rendah terutama dengan pola KUR.

\section{Analisis Deskriptif}

Analisis ini digunakan untuk memberikan gambaran atau deskripsi empiris atas data yang dikumpulkan dalam penelitian (Ferdinand, 2006). Analisis statistik deskriptif yang digunakan pada penelitian ini adalah nilai indeks. Nilai indeks digunakan untuk mendapatkan gambaran mengenai derajad persepsi responden atas variabel yang akan diteliti. Perumusan untuk menghitung nilai indeks adalah sebagai berikut :
Nilai Indeks $=\frac{((\% \mathrm{~F} 1 \times 1)+(\% \mathrm{~F} 2 \times 2)+(\% \mathrm{~F} 3 \times 3)+(\% \mathrm{~F} 4 \times 4)+(\% \mathrm{~F} 5 \times 5))}{5}$

Oleh karena jawaban responden tidak berangkat dari angka 0 , tetapi mulai angka 1 hingga 5, maka angka indeks yang dihasilkan akan berangkat dari angka 5 hingga 100 dengan rentang sebesar 95 . Dengan menggunakan kriteria tiga kotak (Three-box method), maka rentang sebesar 95 dibagi tiga akan menghasilkan rentang sebesar 31,67 yang akan digunakan sebagai dasar interpretasi nilai indeks

$$
\begin{aligned}
& 5.00-36.67: \text { Rendah } \\
& 36.68-68.35: \text { Sedang } \\
& 68.36-100: \text { Tinggi }
\end{aligned}
$$

\section{Nilai Indeks Respon Terhadap Variabel Modal Sosial $\left(\mathbf{X}_{1}\right)$}

Tanggapan responden terhadap indicator dari variable Modal Sosial masing-masing dalam pernyataan sebagai berikut, Tabel 4.5 dibawah ini.

\begin{tabular}{|c|c|c|c|c|c|c|c|c|}
\hline \multirow{2}{*}{ No } & \multirow{2}{*}{ Indikator } & \multicolumn{6}{|c|}{ Jumlah } & \multirow{2}{*}{ Indeks } \\
\hline & & STS & TS & $\mathbf{N}$ & $\mathbf{S}$ & SS & Jumlah & \\
\hline \multirow{2}{*}{1} & \multirow{2}{*}{$\begin{array}{l}\text { Pengusaha dapat } \\
\text { dipercaya }\end{array}$} & 1 & 3 & 16 & 27 & 32 & 79 & \multirow[t]{2}{*}{81.82} \\
\hline & & $1.3 \%$ & $3.8 \%$ & $20.3 \%$ & $34.2 \%$ & $40.5 \%$ & $100 \%$ & \\
\hline \multirow{2}{*}{2} & \multirow{2}{*}{$\begin{array}{l}\text { Hubungan yang baik } \\
\text { sesama pengusaha }\end{array}$} & - & 5 & 13 & 40 & 21 & 79 & \multirow[t]{2}{*}{79.5} \\
\hline & & - & $6.3 \%$ & $16.5 \%$ & $50.6 \%$ & $26.6 \%$ & $100 \%$ & \\
\hline \multirow{2}{*}{3} & \multirow{2}{*}{$\begin{array}{l}\text { Bekerja sama dalam } \\
\text { melakukan usahanya }\end{array}$} & 2 & 2 & 17 & 33 & 25 & 79 & \multirow[t]{2}{*}{79.44} \\
\hline & & $2.5 \%$ & $2.5 \%$ & $21.5 \%$ & $41.8 \%$ & $31.6 \%$ & $100 \%$ & \\
\hline \multirow{2}{*}{4} & \multirow{2}{*}{$\begin{array}{c}\text { Memiliki Jaringan } \\
\text { Bisnis }\end{array}$} & 3 & 4 & 9 & 36 & 27 & 79 & \multirow[t]{2}{*}{80.32} \\
\hline & & $3.8 \%$ & $5.1 \%$ & $11.4 \%$ & $45.6 \%$ & $34.2 \%$ & $100 \%$ & \\
\hline \multirow[b]{2}{*}{5} & \multirow{2}{*}{$\begin{array}{c}\text { Usaha } \\
\text { mengutamakan } \\
\text { kepentingan umum }\end{array}$} & 3 & 2 & 15 & 38 & 21 & 79 & \multirow[b]{2}{*}{78.24} \\
\hline & & $3.8 \%$ & $2.5 \%$ & $19.0 \%$ & $48.1 \%$ & $26.6 \%$ & $100 \%$ & \\
\hline \multicolumn{8}{|c|}{ Rata-rata Indeks } & 79.86 \\
\hline
\end{tabular}

Tabel 4.5

Tanggapan Responden Mengenai Variabel Modal Sosial

Sumber : Data Primer yang diolah, 2019

Tabel 4.5 menunjukkan bahwa rata-rata keseluruhan jawaban responden mengenai variabel Modal Sosial sebesar $79.86 \%$ yang berada dalam katagori tinggi. Berdasarkan hasil perhitungan rata-rata setiap indicator Modal Sosial diatas dipandang sangat mampu meningkatkan kinerja Bisnis UMKM Handy Crab Kota Semarang. Indikator yang paling berperan dari variabel Modal Sosial adalah pengusaha dapat dipercaya. Jadi untuk mendapatkan hasil yang maksimal pengusaha UMKM Handy Crab di Kota Semarang harus memiliki kepercayaan diantara para pengusaha maupun dengan konsumen

\section{Nilai Indeks Respon Terhadap Variabel Manusia $\left(\mathbf{X}_{2}\right)$}

Tanggapan responden terhadap indicator dari variable Modal Manusia masing-masing dalam pernyataan sebagai berikut, Tabel 4.6 dibawah ini . 
Tabel 4.6 Tanggapan Responden Mengenai Variabel Modal Manusia.

\begin{tabular}{|c|c|c|c|c|c|c|c|c|}
\hline \multirow{2}{*}{ No } & \multirow{2}{*}{ Indikator } & \multicolumn{6}{|c|}{ Jumlah } & \multirow{2}{*}{ Indeks } \\
\hline & & STS & TS & $\mathbf{N}$ & $\mathbf{S}$ & SS & Jumlah & \\
\hline \multirow{2}{*}{1} & \multirow{2}{*}{$\begin{array}{c}\text { Pendidikan berperan } \\
\text { penting }\end{array}$} & 1 & 5 & 12 & 40 & 21 & 79 & \multirow{2}{*}{78.98} \\
\hline & & $1.3 \%$ & $6.3 \%$ & $15.2 \%$ & $50.6 \%$ & $26.6 \%$ & $100 \%$ & \\
\hline \multirow[b]{2}{*}{2} & \multirow{2}{*}{$\begin{array}{c}\text { Menggunakan } \\
\text { teknologi untuk } \\
\text { menciptakan } \\
\text { keunggulan }\end{array}$} & 1 & 5 & 14 & 35 & 24 & 79 & \multirow[b]{2}{*}{79.24} \\
\hline & & $1.3 \%$ & $6.3 \%$ & $17.7 \%$ & $44.3 \%$ & $30.4 \%$ & $100 \%$ & \\
\hline \multirow{2}{*}{3} & \multirow{2}{*}{$\begin{array}{l}\text { Ketrampilan } \\
\text { mendukung usaha }\end{array}$} & 2 & 4 & 19 & 31 & 23 & 79 & \multirow[t]{2}{*}{77.46} \\
\hline & & $2.5 \%$ & $5.1 \%$ & $24.1 \%$ & $39.2 \%$ & $29.1 \%$ & $100 \%$ & \\
\hline \multirow{2}{*}{4} & \multirow{2}{*}{$\begin{array}{l}\text { Pengalaman } \\
\text { mendukung usaha }\end{array}$} & 3 & 5 & 17 & 27 & 27 & 79 & \multirow{2}{*}{77.74} \\
\hline & & $3.8 \%$ & $6.3 \%$ & $21.5 \%$ & $34.2 \%$ & $34.2 \%$ & $100 \%$ & \\
\hline \multirow{2}{*}{5} & \multirow{2}{*}{$\begin{array}{c}\text { Pelatihan mendukung } \\
\text { usaha }\end{array}$} & 1 & 7 & 13 & 37 & 21 & 79 & \multirow{2}{*}{77.76} \\
\hline & & $1.3 \%$ & $8.9 \%$ & $16.5 \%$ & $46.8 \%$ & $26.6 \%$ & $100 \%$ & \\
\hline \multicolumn{8}{|c|}{ Rata-rata Indeks } & 78.24 \\
\hline
\end{tabular}

Sumber : Data Primer yang diolah, 2019

Berdasarkan tabel 4.6, menunjukkan bahwa rata-rata keseluruhan jawaban responden mengenai variabel Modal Manusia sebesar $78.24 \%$ yang berada dalam katagori tinggi. Berdasarkan hasil perhitungan rata-rata setiap indikator Modal Manusia diatas dipandang sangat mampu meningkatkan kinerja Bisnis . Salah satu Indikator Modal Manusia yaitu menggunakan teknologi untuk menciptakan keunggulan memiliki score tertinggi 79,24 . Hal itu terbukti semakin teknologi yang semakin baik dan mampu membuat kerajinan tangan yang kreatif ternyata sangat mendukung peningkatan kinerja bisnis.

\section{Nilai Indeks Respon Terhadap Variabel Kebijakan Pemerintah ( $\mathbf{Z}$ )}

Tanggapan responden terhadap masingmasing indicator variable kebijakan pemerintah $(\mathrm{Z})$ dapat dilihat dalam table 4.7 di bawah.

Tabel 4.7 Hasil Tanggapan Responden Mengenai Variabel Kebijakan Pemerintah

\begin{tabular}{|c|c|c|c|c|c|c|c|c|}
\hline \multirow{2}{*}{ No } & \multirow{2}{*}{ Indikator } & \multicolumn{6}{|c|}{ Jumlah } & \multirow{2}{*}{ Indeks } \\
\hline & & STS & TS & $\mathbf{N}$ & $\mathbf{S}$ & SS & Jumlah & \\
\hline \multirow{2}{*}{1} & \multirow{2}{*}{$\begin{array}{c}\text { Fasilitas } \\
\text { pemerintah }\end{array}$} & - & 11 & 20 & 28 & 20 & 79 & \multirow[t]{2}{*}{74.36} \\
\hline & & - & $13.9 \%$ & $25.3 \%$ & $35.4 \%$ & $25.3 \%$ & $100 \%$ & \\
\hline \multirow{4}{*}{2} & \multirow{2}{*}{$\begin{array}{c}\text { Program } \\
\text { pemerintah }\end{array}$} & - & 9 & 16 & 32 & 22 & 79 & \multirow[t]{2}{*}{76.94} \\
\hline & & - & $11.4 \%$ & $20.3 \%$ & $40.5 \%$ & $27.8 \%$ & $100 \%$ & \\
\hline & \multirow{2}{*}{$\begin{array}{c}\text { Tingkat suku } \\
\text { bunga kredit yang } \\
\text { mendukung }\end{array}$} & 1 & 8 & 8 & 34 & 28 & 79 & \multirow[b]{2}{*}{80.16} \\
\hline & & $13 \%$ & $10.1 \%$ & $10.1 \%$ & $43.0 \%$ & $35.4 \%$ & $100 \%$ & \\
\hline \multirow[b]{2}{*}{4} & \multirow{2}{*}{$\begin{array}{c}\text { Pembinaan yang } \\
\text { dilakukan } \\
\text { pemerintah } \\
\end{array}$} & - & 6 & 10 & 39 & 24 & 79 & \multirow[b]{2}{*}{80.58} \\
\hline & & & $7.6 \%$ & $12.7 \%$ & $49.4 \%$ & $30.4 \%$ & $100 \%$ & \\
\hline \multirow{2}{*}{5} & \multirow{2}{*}{$\begin{array}{l}\text { Peraturan UMKM } \\
\text { yg mendukung }\end{array}$} & - & 12 & 21 & 35 & 11 & 79 & \multirow[t]{2}{*}{71.38} \\
\hline & & - & $15.2 \%$ & $26.6 \%$ & $44.3 \%$ & $13.9 \%$ & $100 \%$ & \\
\hline
\end{tabular}

Berdasarkan tabel 4.7 menunjukkan bahwa rata-rata keseluruhan jawaban responden mengenai variabel Kebijakan Pemerintah.sebesar $76.68 \%$ yang berada dalam katagori tinggi. Berdasarkan hasil perhitungan rata-rata setiap indikator Variabel
Kebijakan Pemerintah.diatas dipandang sangat mampu meningkatkan kinerja bisnis UMKM Handy $\mathrm{Crab} /$ kerajinan tangan kota Semarang. Indikator yang paling berperan dalam kebijakan pemerintah 
adalah pembinaan yang dilakukan pemerintah sebesar $80,58 \%$ dan tingkat suku bunga kredit yang mendukung usaha UMKM sebesar 80,16\% /Ini m,enunjukkan kemajuan handy crab/kerajinan tangan supaya maju harus ada keterlibatan pemerintah terutama pembinaan atau pemberdayaan
UMKM Handy Crab/kerajinan tangan serta kredit yang mendukung seperti program KUR

Nilai Indeks Respon Terhadap Variabe Kinerja Bisnis (Y)

Tanggapan responden terhadap masingmasing indicator dari variable kinerja bisnis $(\mathrm{Y})$ adalah seperti table 4.8 .

Tabel 4.8 Hasil Tanggapan Responden Mengenai Variabel Kinerja Bisnis (Y)

\begin{tabular}{|c|c|c|c|c|c|c|c|c|}
\hline \multirow{2}{*}{ No } & \multirow{2}{*}{ Indikator } & \multicolumn{6}{|c|}{ Jumlah } & \multirow{2}{*}{ Indeks } \\
\hline & & STS & TS & $\mathbf{N}$ & $\mathbf{S}$ & SS & Jumlah & \\
\hline \multirow{2}{*}{1} & \multirow{2}{*}{$\begin{array}{c}\text { Peningkatan } \\
\text { pendapatan usaha }\end{array}$} & 1 & 5 & 17 & 39 & 17 & 79 & \multirow[b]{2}{*}{76,70} \\
\hline & & $1,3 \%$ & $6,3 \%$ & $21,5 \%$ & $49.4 \%$ & $21,5 \%$ & $100 \%$ & \\
\hline \multirow{2}{*}{2} & \multirow{2}{*}{$\begin{array}{c}\text { Jumlah pelanggan } \\
\text { meningkat }\end{array}$} & 3 & 3 & 18 & 24 & 31 & 79 & \multirow[b]{2}{*}{79,48} \\
\hline & & $3,8 \%$ & $3,8 \%$ & $22,8 \%$ & $30,4 \%$ & $39,2 \%$ & $100 \%$ & \\
\hline \multirow{2}{*}{3} & \multirow{2}{*}{$\begin{array}{c}\text { Keberhasilan } \\
\text { dalam menetapkan } \\
\text { target }\end{array}$} & 1 & 3 & 10 & 44 & 21 & 79 & \multirow[b]{2}{*}{80,56} \\
\hline & & $1,3 \%$ & $3,8 \%$ & $12,7 \%$ & $55,7 \%$ & $26,6 \%$ & $100 \%$ & \\
\hline \multirow{2}{*}{4} & \multirow{2}{*}{$\begin{array}{l}\text { Aktivitas yang } \\
\text { tinggi para pekerja }\end{array}$} & 2 & 3 & 11 & 38 & 25 & 79 & \multirow[b]{2}{*}{80,44} \\
\hline & & $2,5 \%$ & $3,8 \%$ & $13,9 \%$ & $48,4 \%$ & $31,6 \%$ & $100 \%$ & \\
\hline \multirow{2}{*}{5} & \multirow{2}{*}{$\begin{array}{l}\text { Peningkatan } \\
\text { penjualan }\end{array}$} & 1 & 7 & 21 & 39 & 11 & 79 & \multirow[b]{2}{*}{73,20} \\
\hline & & $1,3 \%$ & $8,9 \%$ & $26,6 \%$ & $49,4 \%$ & $13,9 \%$ & $100 \%$ & \\
\hline \multicolumn{8}{|c|}{ Rata-rata Indeks } & 78,08 \\
\hline
\end{tabular}

Sumber : Data Primer yang diolah, 2019

Berdasarkan tabel 4.9 menunjukkan bahwa rata-rata keseluruhan jawaban responden mengenai variabel Kinerja Bisnis sebesar 78.08\% yang berada dalam katagori tinggi. Berdasarkan hasil perhitungan rata-rata setiap indikator dari vatoiabel kinerja bisnis diatas dipandang sangat mampu meningkatkan Kinerja Bisnis UKM Handy Crab/kerajinan tangan di Kota Semarang Menurut responden indikator keberhasilan dalam menetapkan target dngan indeks $80-56 \%$ dan aktivitas yang tinggi para pekerja menggambarkan tingkat kinerja bisnis, sehingga karyawan dikatakan pencapaian kinerja bisnis pengusaha mampu menyelesaikan dengan baik. Upaya yang dapat dilakukan pengusaha UMKM Handy Crab untuk meningkatkan kinerja bisnis dari Pernyataan terbuka adalah paham terhadap target yang diberikan, semangat untuk bekerja, tidak pantang menyerah, tidak takut untuk menyampaikan pendapat untuk kebaikan perusahaan dan lebih mengembangkan ide - ide kreatif.

\section{Analisis Data Kuantitatif Uji Validitas}

Menurut Imam Ghozali (2005) uji validitas digunakan untuk mengetahui sah / valid tidak suatu kuisioner, suatu kuisioner dinyatakan valid jika Pernyataan pada kuisioner mampu mengungkapkan sesuatu yang akan diukur oleh kuisioner tersebut.
Tingkat Validitas dapat diukur dengan cara membandingkan nilai signifikansi. Adapun kriterianya sebagai berikut:

a. Pernyataan tersebut dikatakan valid jika signifikansi $<0,05$ dan

b. Jika nilai signifikansi nya $>0,05$ maka Pernyataan tersebut dikatakan tidak valid.

Berdasarkan uji validitas seperti tabel dibawah ini:

Berdasarkan uji validitas yang telah dilakukan menggunakan SPSS seperti tabel dibawah ini:

Uji Validitas Modal Sosial $\left(\mathbf{X}_{1}\right)$

Tabel 4.9 Uji Validitas Modal Sosial (X1)

\begin{tabular}{|c|l|c|c|c|}
\hline No. & Pernyataan & Sig & Standar Sig & Keterangan \\
\hline 1 & Pernyataan 1 & 0,000 & & Valid \\
\hline 2 & Pernyataan 2 & 0,000 & \multirow{4}{*}{$<0,05$} & Valid \\
\hline 3 & Pernyataan 3 & 0,000 & Valid \\
\cline { 1 - 2 } & Pernyataan 4 & 0,000 & Valid \\
\hline 5 & Pernyataan 5 & 0,000 & & Valid \\
\hline
\end{tabular}

Sumber: Data diolah, 2019

Berdasarkan tabel 4.10 di atas dapat diketahui bahwa seluruh Pernyataan memiliki tingkat signifikansi $0,000(<0,05)$ sehingga dapat disimpulkan bahwa seluruh Pernyataan pada variabel Modal Sosial adalah valid.

\section{Uji Validitas Modal Manusia (X2)}

Tabel 4.10 Uji Validitas Modal Manusia (X2)

\begin{tabular}{|l|l|c|c|c|}
\hline No. & Pernyataan & Sig & Standar Sig & Keterangan \\
\hline 1 & Pernyataan 1 & 0,000 & \multirow{2}{*}{$<0,05$} & Valid \\
\cline { 1 - 3 } 2 & Pernyataan 2 & 0,000 & & Valid \\
\hline
\end{tabular}




\begin{tabular}{|l|l|l|l|l|}
\hline 3 & Pernyataan 3 & 0,000 & & Valid \\
\hline 4 & Pernyataan 4 & 0,000 & & Valid \\
\hline 5 & Pernyataan 5 & 0,000 & & Valid \\
\hline
\end{tabular}

Sumber: Data diolah, 2019

Berdasarkan tabel 4.9 di atas dapat diketahui bahwa seluruh Pernyataan memiliki tingkat signifikansi $0,000 \quad(<0,05) \quad$ sehingga dapat disimpulkan bahwa seluruh Pernyataan pada variabel Modal Manusia adalah valid

Uji Validitas Kebijakan Pemerintah ( $Z$ )

Tabel 4.11

Uji Validitas Kebijakan Pemerintah (Z)

\begin{tabular}{|l|l|c|c|c|}
\hline No. & Pernyataan & Sig & Standar Sig & Keterangan \\
\hline 1 & Pernyataan 1 & 0,000 & & Valid \\
\hline 2 & Pernyataan 2 & 0,000 & & Valid \\
\hline 3 & Pernyataan 3 & 0,000 & \multirow{2}{*}{$<0,05$} & Valid \\
\hline 4 & Pernyataan 4 & 0,000 & & Valid \\
\hline 5 & Pernyataan 5 & 0,044 & & Valid \\
\cline { 1 - 2 } & & & & \\
\cline { 1 - 2 } & & &
\end{tabular}

Sumber: Data diolah, 2019

Berdasarkan tabel $4.10 \mathrm{di}$ atas dapat diketahui bahwa seluruh Pernyataan memiliki tingkat signifikansi $0,000 \quad(<0,05) \quad$ sehingga dapat disimpulkan bahwa seluruh Pernyataan pada variabel Kebijakan Pemerintah adalah valid.

Uji Validitas Kinerja Bisnis (Y)

Tabel 4.12

Uji Validitas Kinerja Bisnis (Y)

\begin{tabular}{|l|l|c|c|c|}
\hline No. & Pernyataan & Sig & Standar Sig & Keterangan \\
\hline 1 & Pernyataan 1 & 0,000 & & Valid \\
\hline 2 & Pernyataan 2 & 0,000 & \multirow{4}{*}{$<0,05$} & Valid \\
\cline { 1 - 2 } & Pernyataan 3 & 0,000 & Valid \\
\hline 4 & Pernyataan 4 & 0,000 & Valid \\
\hline 5 & Pernyataan 5 & 0,001 & & Valid \\
\hline
\end{tabular}

Sumber: Data diolah, 2019

Berdasarkan tabel 4.12 di atas dapat diketahui bahwa seluruh Pernyataan memiliki tingkat signifikansi $0,000(<0,05)$ sehingga dapat disimpulkan bahwa seluruh Pernyataan pada variabel Kinerja Bisnis adalah valid.

\section{Uji Reliabilitas}

Reliabilitas adalah indeks yang menunjukkan sejauh mana suatu alat ukur dipakai dua kali untuk mengukur gejala yang sama dan hasil pengukurannya relatif sama maka alat ukur tersebut reliable. Dengan kata lain, reliabilitas menunjukkan konsistensi suatu alat ukur dalam mengukur gejala yang sama.
Reliabilitas dilakukan untuk mengukur konsistensi konstruk atau variabel penelitian suatu kuisioner dikatakan Reliable atau handal jika jawaban seseorang terhadap Pernyataan adalah konsisten atau stabil dari waktu ke waktu untuk mengukur Reliabilitas dengan Uji Statistik Cronbach Alpha $(\alpha)$ suatu variabel dikatakan reliable (handal) jika memiliki nilai Cronbach Alpha $>0,600$.

Adapun hasil dari pengujian reliabilitas adalah sebagai berikut :

Tabel 4.13

Hasil Uji Reliabilitas

\begin{tabular}{|l|c|c|}
\hline \multicolumn{1}{|c|}{ Variabel } & Nilai r Alpha & Keterangan \\
\hline Modal Sosial (X1) & 0,875 & Reliabel \\
\hline Modal Manusia (X2) & 0,864 & Reliabel \\
\hline Kebijakan Pemerintah (Z) & 0,608 & Reliabel \\
\hline Kinerja bisnis (Y) & 0,635 & Reliabel \\
\hline
\end{tabular}

Sumber : Data diolah, 2019

Berdasarkan tabel diatas dapat diketahui seluruh variabel memiliki nilai Cronbach Alpha > 0,600 , hal ini berarti bahwa seluruh variabel dalam penelitian ini reliable (handal).

\section{Uji Klasik.}

\section{Uji Multikolonieritas}

Uji Multikolineritas bertujuan menguji apakah dalam model regresi ditemukan adanya korelasi antar variabel bebas. Model regresi yang baik seharusnya tidak terjadi korelasi diantara variabel bebas jika variabel bebas berkolerasi maka variabel-variabel ini tidak ortogonal variabel ortogonal adalah variabel bebas yang nilai korelasi antar sesama variabel bebas $=0$.

Multikolinearitas dapat dilihat dari nilai Tolerance dan Variance Inflation Factor(VIF). Menurut Ghozali (2005) cara mendeteksi terhadap adanya Multikolineritas dalam model regresi adalah sebagai berikut :

a. Besarnya Variabel Inflation Factor (VIF) pedoman suatu model regresi yang bebas Multikolineritas yaitu nilai VIF $\leq 10$.

b. Besarnya Tolerance pedoman suatu model regresi yang bebas Multikolineritas yaitu nilai Tolerance $\geq 0,1$

Pengujian multikolinieritas menggunakan software SPSS Versi 16 dapat dilihat pada tabel di bawah ini:

Tabel 4.14 Uji Multikolinieritas

\begin{tabular}{|c|l|r|r|c|}
\hline No. & \multicolumn{1}{|c|}{ Variabel } & Tollerance & VIF & Keterangan \\
\hline 1 & Modal sosial & .659 & 1.517 & Bebas Multikolinieritas \\
\hline 2 & Modal Manusia & .715 & 1.399 & Bebas Multikolinieritas \\
\hline 3 & Kebijakan Pemerintah & .858 & 1.165 & Bebas Multikolinieritas \\
\hline
\end{tabular}

Sumber: Sumber: Output SPSS, 2019 
Berdasarkan tabel 4.14 diatas dapat disimpulkan bahwa variabel pada penelitian ini bebas multikolinieritas.

\section{Uji Heteroskedastisitas}

Model regresi yang baik adalah yang homoskedastisitas atau terjadi heterokedastisitas. Agar data tidak terjadi problem heteroskedastisitas dapat dilihat dari uji glejser. Menurut Ghozali (2007) bahwa jika variable independen signifikan secara statistic mempengaruhi variable dependen, maka ada indikasi terjadi heteroskedastisitas, begitu sebaliknya jika tidak ada satupun variable independen yang signifikan dengan probabilitas signifikanasinya di atas tingkat kepercayaan 5\% secara statistik maka tidak terjadi problem heteroskedastisitas. Berikut hasil pengujian heteroskedastititas:

Tabel 4.16 Uji Glejser Coefficients ${ }^{\mathrm{a}}$

\begin{tabular}{|c|c|c|c|c|c|c|}
\hline & \multirow[b]{2}{*}{ Model } & \multicolumn{2}{|c|}{$\begin{array}{l}\text { Unstandardized } \\
\text { Coefficients }\end{array}$} & \multirow{2}{*}{$\begin{array}{c}\begin{array}{c}\text { Standardized } \\
\text { Coefficients }\end{array} \\
\text { Beta }\end{array}$} & \multirow[b]{2}{*}{$\mathrm{t}$} & \multirow[b]{2}{*}{ Sig. } \\
\hline & & B & Std. Error & & & \\
\hline \multirow[t]{4}{*}{1} & (Constant) & $7.842 \mathrm{E}-16$ & 1.541 & & .000 & 1.000 \\
\hline & Modal sosial & .000 & .070 & .000 & .000 & 1.000 \\
\hline & Modal Manusia & .000 & .067 & .000 & .000 & 1.000 \\
\hline & $\begin{array}{l}\text { Kebijakan } \\
\text { Pemerentah }\end{array}$ & .000 & .091 & .000 & .000 & 1.000 \\
\hline
\end{tabular}

a. Dependent Variable: Unstandardized Residual

Penjelasan pada table tersebut di atas terlihat bahwa nilai signifikansinya untuk semua variabel Modal Sosial, Modal Manusia, Kebijakan pemerintah terhadap kinerja bisnis melebihi dari batas nilai signifikansi > 0,05 sehingga dapat disimpulkan bahwa uji tersebut tidak terjadi problem heteroskedastisitas.

Analisis Regresi Moderasi (MRA). $\beta_{1}=\beta_{2}=$ Konstante.. e. $=$ standard eror
Dalam penelitian ini digunakan analisis Regresi Moderasi (MRA) maupun sebelum ada moderasi. Regresi Linier Berganda sebelum ada moderasi $\mathrm{Y}=\beta_{1} \mathrm{X}_{1}+\beta_{2} \mathrm{X}_{2}+\mathrm{e}$ .Persamaan. 1.

Dimana:

$\mathrm{Y}=$ Kinerja Bisnis, $\mathrm{X}_{1}=$ Variabel Modal Sosial, $\mathrm{X}_{2}$ = Varoabel Modal Manusia

Tabel 4.17 - Coefficients ${ }^{\mathbf{a}}$

\begin{tabular}{|c|c|c|c|c|c|c|c|}
\hline \multirow[b]{2}{*}{ Model } & \multicolumn{2}{|c|}{$\begin{array}{l}\text { Unstandardized } \\
\text { Coefficients }\end{array}$} & \multirow{2}{*}{$\begin{array}{c}\text { Standardized } \\
\text { Coefficients } \\
\text { Beta }\end{array}$} & \multirow[b]{2}{*}{$\mathrm{t}$} & \multirow[b]{2}{*}{ Sig. } & \multicolumn{2}{|c|}{ Collinearity Statistics } \\
\hline & B & $\begin{array}{l}\text { Std. } \\
\text { Error }\end{array}$ & & & & Tolerance & VIF \\
\hline (Constant) & 6.635 & 1.313 & & 5.052 & .000 & & \\
\hline total modal sosial & .388 & .068 & .507 & 5.687 & .000 & .719 & 1.392 \\
\hline $\begin{array}{c}\text { Total Modal } \\
\text { Manusia }\end{array}$ & .263 & .067 & .350 & 3.925 & .000 & .719 & 1.392 \\
\hline
\end{tabular}

a. Dependent Variable: total kinerja bisnis

Tabel 4.18 - Model Summary

\begin{tabular}{|c|r|r|r|r|}
\hline Model & $\mathrm{R}$ & R Square & $\begin{array}{c}\text { Adjusted R } \\
\text { Square }\end{array}$ & $\begin{array}{c}\text { Std. Error of the } \\
\text { Estimate }\end{array}$ \\
\hline 1 & $.753^{\mathrm{a}}$ & .567 & .555 & 1.945 \\
\hline
\end{tabular}

a. Predictors: (Constant), Total Modal Manusia, total modal sosial 
Dari table 4.17 dapat dibuat persamaan regresi linier berganda sebagai berikut:

$$
\begin{aligned}
& \mathbf{Y}=\mathbf{0 , 5 0 7} \mathbf{X}_{\mathbf{1}}+\mathbf{0 , 3 5 0} \mathbf{X}_{\mathbf{2}} \\
& \text { Nilai t (5.687) (3.925) } \quad \mathrm{R}^{2} \mathrm{Adj}=0.555
\end{aligned}
$$

Dari persamaan tersebut di atas dapat disimpulkan sbb:

$\beta_{1}=0,807$ memiliki tanda positi, yang bermagna bila semakin baik modal social pengusaha UKM Hendy Crab maka akan semakin meningkat kinerja bisnis.

$\beta_{2}=0,507$ memiliki tanda positi, yang bermakna semakin baik modal manusia pengusaha UKM Hendy Crab maka semakin meningkat kinerja bisnisnya.

Berdasarkan persamaan (1) dapat diketahui bahwa variabel modal sosial merupakan variabel yang paling dominan terhadap variabel kinerja bisnis.

\section{Pengujian Hipotesis \\ Pengaruh Modal Sosial terhadap Kinerja Bisnis}

Kriteria pengujian uji $\mathrm{t}$ adalah sebagai berikut :

a. Jika Sig < 0,05 maka Ho ditolak dan $\mathrm{Ha}$ diterima berarti ada pengaruh signifikan variabel independen secara individual terhadap variabel dependen.

b. Jika Sig > 0,05 maka Ha ditolak dan H0 diterima berarti tidak ada pengaruh signifikan variabel independen secara individual terhadap variabel dependen.

Hasil perhitungan untuk variabel karakteristik individu yang telah dilakukan diperoleh nilai $\mathrm{t}_{\text {hitung }} 5.687>\mathrm{t}_{\text {tabel }} 1.66437$ dengan signifikansi sebesar $0,000<0,05$ maka Ho ditolak dan $\mathrm{Ha}$ diterima berarti ada pengaruh signifikan. Dengan hasil tersebut dapat disimpulkan bahwa pengujian tersebut menunjukkan pengaruh yang positif dan signifikan antara Modal Sosial terhadap Kinerja Bisnis.

\section{Pengaruh Modal Manusia terhadap Kinerja Bisnis}

Kriteria pengujian uji t adalah sebagai berikut : a. Jika Sig < 0,05 maka Ho ditolak dan Ha diterima berarti ada pengaruh signifikan variabel independen secara individual terhadap variabel dependen.

b. Jika Sig > 0,05 maka Ha ditolak dan H0 diterima berarti tidak ada pengaruh signifikan variabel independen secara individual terhadap variabel dependen.

Hasil perhitungan untuk variabel Modal Manusia yang telah dilakukan diperoleh nilai $\mathrm{t}_{\text {hitung }} 3.925>\mathrm{t}_{\text {tabel }} 1.66437$ dengan signifikansi sebesar $0,000<0,05$ maka Ho ditolak dan Ha diterima berarti ada pengaruh signifikan. Dengan hasil tersebut dapat disimpulkan bahwa pengujian tersebut menunjukkan pengaruh yang positif dan signifikan antara Modal Manusia terhadap Kinerja Bisnis.

\section{Koefesien Diterminasi $\left(\mathbf{R}^{2}\right)$ Adj.}

Koefisien Determinasi ini digunakan untuk mengetahui seberapa besar kemampuan variabel bebas dalam menerangkan variabel terikat. Nilai determinasi ditentukan dengan nilai Adjusted $R$ Square seperti yang ditunjukkan pada Tabel 4.18 diatas

Berdasarkan hasil perhitungan regresi I, diperoleh nilai Koefisien Determinasi yang disesuaikan (adjusted $R^{2}$ ) adalah= $0.555(55,5 \%)$ artinya persen variasi dari semua variabel bebas dapat menerangkan variabel terikat, sedangkan sisanya sebesar $44,5 \%$ diterangkan oleh variabel lain yang tidak diajukan dalam penelitian ini.

\section{Analisis regresi Moderasi .}

$\mathrm{Y}=\beta_{1} \mathrm{X}_{1}+\beta_{2} \mathrm{X}_{2}+\beta_{2} \mathrm{Z}^{*} \mathrm{X}_{1} * \mathrm{X}_{2}+$ e........................Persamaan. (2).

Dimana:

$\mathrm{Y}=$ Kinerja Bisnis

$\mathrm{X}_{1} \quad=$ Variabel Modal Sosial

$\mathrm{X}_{2} \quad=$ Varoabel Modal Manusia.

$\mathrm{Z} \quad=$ Variabe Kebijakan Pemerintah

$\mathrm{Z} * \mathrm{X} 1 * \mathrm{X} 2=$ Interaksi Kebijakan

Pem*Modal Sosial*Modal manusia

$\beta_{1}=\beta_{2} \quad=$ Konstante.

e. $\quad=$ standard eror

\begin{tabular}{|c|c|c|c|c|c|}
\hline \multirow[b]{2}{*}{ Model } & \multicolumn{2}{|c|}{ Unstandardized Coefficients } & \multirow{2}{*}{$\frac{\text { Standardized Coefficients }}{\text { Beta }}$} & \multirow[b]{2}{*}{$\mathrm{t}$} & \multirow[b]{2}{*}{ Sig. } \\
\hline & $\mathrm{B}$ & Std. Error & & & \\
\hline (Constant) & 8,326 & 1,733 & & 4,803 & , 000 \\
\hline total modal sosial &, 307 & 087 & ,401 & 3,533 & ,001 \\
\hline Total Modal Manusia &, 168 & ,092 & ,223 & 1,813 & ,074* \\
\hline interaksimsk & , 000 & , 000 & ,232 & 1,480 & ,043 \\
\hline
\end{tabular}

Tabel 4.19 Coefficients

a. Dependent Variable: Total Kinerja Bisnis 
Tabel 4.20 Model Summary

\begin{tabular}{|c|c|c|c|c|c|c|c|c|c|}
\hline \multirow[b]{2}{*}{$\begin{array}{c}\text { Mod } \\
\text { el }\end{array}$} & \multirow[b]{2}{*}{$\mathrm{R}$} & \multirow[b]{2}{*}{$\begin{array}{c}\mathrm{R} \\
\text { Square }\end{array}$} & \multirow[b]{2}{*}{$\begin{array}{l}\text { Adjusted } \\
\text { R Square }\end{array}$} & \multirow{2}{*}{$\begin{array}{l}\text { Std. Error } \\
\text { of the } \\
\text { Estimate }\end{array}$} & \multicolumn{5}{|c|}{ Change Statistics } \\
\hline & & & & & $\begin{array}{l}\text { R Square } \\
\text { Change }\end{array}$ & F Change & df1 & df2 & $\begin{array}{c}\text { Sig. F } \\
\text { Change }\end{array}$ \\
\hline 1 &, $761^{\mathrm{a}}$ & ,579 & ,562 & 1,930 &, 579 & 34,385 & 3 & 75 &, 000 \\
\hline
\end{tabular}

a. Predictors: (Constant), interaksimsk, total modal sosial, Total Modal Manusia

Berdasarkan tabel 4.19 dapat dikembangkan persamaan Regresi dengan Moderasi sebagai berikut: $\mathrm{Y}=0,401 \mathrm{X}_{1}+0,223 \mathrm{X}_{2}+0,232 \mathrm{X}_{1} * \mathrm{X}_{2} * \mathrm{Z}$ ..Persamaan

$\begin{array}{ll}\text { Nilai } t & (3,533 \\ \mathrm{R}^{2} \text { Adj } & =0,562\end{array}$

Dari persamaan (2) di atas dapat disimpulkan sbb: $\beta_{1}=0,401$ memiliki tanda positi, yang bermagna bila semakin baik modal social pengusaha UKM Hendy Crab maka akan semakin meningkat kinerja bisnis.

$\beta_{2}=0,223$ memiliki tanda positi, yang bermakna semakin baik modal manusia pengusaha UKM Hendy Crab maka semakin meningkat kinerja bisnisnya.

$\beta_{3}=0,232$ memiliki tanda positif, yang bermakna semakin baik interaksimodal sosial, modal manusia dengan kebijakan pemerintah maka akan semakin meningkat kinerja bisnis.

Berdasarkan persamaan (2) dapat diketahui bahwa variabel modal sosial merupakan variabel yang paling dominan terhadap variabel kinerja bisnis.

\section{Pengujian Hipotesis}

\section{Pengaruh Modal Manusia terhadap Kinerja Bisnis dengan moderasi kebijakan pemerintah}

Kriteria pengujian uji $t$ adalah sebagai berikut : c. Jika Sig $<0,10$ maka Ho ditolak dan Ha diterima berarti ada pengaruh signifikan variabel independen secara individual terhadap variabel dependen.

d. Jika Sig > 0,10 maka Ha ditolak dan H0 diterima berarti tidak ada pengaruh signifikan variabel independen secara individual terhadap variabel dependen.

Hasil perhitungan untuk variabel Modal Manusia yang telah dilakukan diperoleh nilai $t_{\text {hitung }} 1,813>t_{\text {tabel }} 1.66437$ dengan signifikansi sebesar 0,074>0,10 maka Ho ditolak dan Ha diterima berarti ada pengaruh signifikan. Dengan hasil tersebut dapat disimpulkan bahwa pengujian tersebut menunjukkan bahwa kebijaka pemerintah menjadikan moderasi bagi variabel Modal Manusia terhadap Kinerja Bisnis.
Pengaruh Modal Sosial terhadap Kinerja Bisnis dengan moderasi kebijakan pemerintah

Kriteria pengujian uji $\mathrm{t}$ adalah sebagai berikut :

e. Jika Sig $<0,05$ maka Ho ditolak dan Ha diterima berarti ada pengaruh signifikan variabel independen secara individual terhadap variabel dependen.

f. Jika Sig > 0,05 maka Ha ditolak dan H0 diterima berarti tidak ada pengaruh signifikan variabel independen secara individual terhadap variabel dependen.

Hasil perhitungan untuk variabel Modal Manusia yang telah dilakukan diperoleh nilai $t_{\text {hitung }} 1,813>t_{\text {tabel }} 1.664$ dengan signifikansi sebesar 0,01 < 0,05 maka Ho ditolak dan Ha diterima berarti tidak ada pengaruh signifikan. Dengan hasil tersebut dapat disimpulkan bahwa pengujian tersebut menunjukkan bahwa kebijaka pemerintah menjadikan moderasi bagi variabel Modal Sosial terhadap Kinerja Bisnis.

\section{Koefesien Diterminasi $\left(\mathbf{R}^{2}\right)$ Adj.}

Koefisien Determinasi ini digunakan untuk mengetahui seberapa besar kemampuan variabel bebas dalam menerangkan variabel terikat. Nilai determinasi ditentukan dengan nilai Adjusted $R$ Square seperti yang ditunjukkan pada Tabel 4.20 diatas

Berdasarkan hasil perhitungan regresi I, diperoleh nilai Koefisien Determinasi yang disesuaikan (adjusted $R^{2}$ ) adalah= 0,562 (56,2\%) artinya persen variasi dari semua ariable bebas dapat menerangkan ariable terikat, sedangkan sisanya sebesar 43,2\% diterangkan oleh variable lain yang tidak diajukan dalam penelitian ini.

\section{PEMBAHASAN.}

\section{Pengaruh Modal sosial terhadap kinerja bisnis.}

Hasil penelitian menunjukkan bahwa ada pengaruh positif dan signifikan antara modal social terhadap kinerja bisnis , artinya bila meningkatkan modal social yang dimiliki pengusaha UKM handy crab/kerajinan tangan di kota Semarang seperti meningkatkan kepercayaan para pengusaha, mengembangkan hubungan yang baik antara para pengusaha dan konsumen,meningkatkan kerja sama antara pengusaha, mengembangkan jaringan bisnis 
dengan semua pihak, serta mengutamakan kepentingan usaha makan akan semakin meningkat kinerja bisnisnya. Menurut Pratisthita et al. (2014) Modal Sosial merupakan nilai-nilai, norma dan trust (rasa saling mempercayai) dalam suatu masyarakat dimana masyarakat saling berpartisipasidan terdapat proses timbal balik di dalamnya. Bourdieu (1986) menyatakan bahwa, volume social capital yang dimiliki oleh seseorang tergantung pada ukuran jejaring koneksi yang dapat dimobilisasikannya serta pada volume modal (ekonomi, budaya, atau simbolis) yang dimilikinya. Ini artinya bahwa, meski relatif tidak dapat direduksi ke modal ekonomi dan budaya yang dimiliki oleh agen tertentu, atau bahkan oleh seluruh agen yang terhubung, social capital tidak pernah independen seluruhnya dari agen karena pertukaran-pertukaran membentuk pengenalan satu sama lain. Hal ini sesuai dengan penelitian Wahyuningrum (2013) yang menyimpulkan bahwa modal insani dan modal sosial memiliki pengaruh langsung terhadap kinerja pada UKM Kerajinan di Depok. Layla Khoirrini dan Lindawati Kartika (2014) menyatakan modal insani dan modal sosial berpengaruh positif dan signifikan terhadap kinerja. Penelitian Andriani juga menunjukkan bahwa modal sosial dapat meningkatkan kinerja (_Andriani \& Zain, 2010).

\section{Pengaruh modal manusai terhadap kinerja bisnis.}

Hasil penelitian menunjukkan bahwa ada pengaruh positi dan signifikan antara modal manusia terhadap kinerja bisnis, magnanya bila meningkatkan modal manusia yang dimiliki pada pengusaha UKM handy crab/kerajinan tangan di kota Semarang seperti meningkatkan peran pendidikanpara pengusaha, meningkatkan ketrampilan, pengalaman , pelatihan serta meningkatkan pemanfaatan teknologi untuk menciptakan keunggulan maka akan semakin meningkatkan kinerja bisnisnya. Ini sesuai dengan peneliti Zuliyati dan Delima (2017) yang menyimpulkan bahwa intellectual capital mempunyai pengaruh positif dan signifikan terhadap kinerja UMKM. Wahyuningrum (2013) yang menyimpulkan bahwa modal insani dan modal sosial memiliki pengaruh langsung terhadap kinerja pada UKM Kerajinan di Depok. Layla Khoirrini dan Lindawati Kartika (2014) menyatakan modal insani dan modal sosial berpengaruh positif dan signifikan terhadap kinerja

\section{Pengaruh Kebijakan Pemerintah memoderasi modal social terhadap kinerja bisnis.}

Hasil penelitian menunjukkan bahwa kebijakan pemerintah memoderasi modal social terhadap kinerja bisnis artinya pengusaha handy crab/kerajinan tangan yang telah memiliki modal social yang baik seperti kepercayaan para pengusaha, mengembangkan hubungan yang baik antara para pengusaha dan konsumen,meningkatkan kerja sama antara pengusaha, mengembangkan jaringan bisnis dengan semua oihak, serta mengutamakan kepentingan usaha dengan dimoderasi kebijakan pemerintah makan akan semakin meningkatkan kinerja bisnisnya. Hal ini sesuai Eka Nila Kencana (2018) menjelaskan peran pemerintah berpengaruh positif dan signifikan terhadap kinerja usaha pelaku usaha industri tenun di Kabupaten Jembrana.

\section{Pengaruh Kebijakan Pemerintah memoderasi modal manusia terhadap kinerja bisnis.}

Hasil penelitian menunjukkan bahwa kebijakan pemerintah memoderasi modal manusia artinya kebijakan pemerintah berinteraksi terhadap modal manusia, maka variable kebijakan pemerintah moderator.Artinya variable kebijakan pemerintah justru memperkuat pengaruh modal manusia terhadap kinerja bisnis. Bontis dan Serenko (2009) berpendapat, modal manusia meliputi tiga faktor, yaitu kompetensi, pengalaman dan pengetahuan yang dimiliki oleh seorang individu. Bagi Hitt, Bieman, Shimizu dan KLochhar (2001) dalam studi mereka mencatat bahwa modal manusia memiliki dua dimensi, yaitu kualitas dan pengalaman. Kegagalan bisnis dan pertumbuhan usaha disebabkan karena pelaku usaha kurang memperhatikan perbaikan diri dalam hal meng-upgrade tingkat kemampuan dan keterampilannya (Surin, Edward, Hussin, \& Wahab, 2017). Kualitas sumber daya manusia yang rendah menjadikan perkembangan UKM tersendat-sendat (Nurainun, 2008)

\section{PENUTUP}

\section{Kesimpulan Rumusan Masalah}

Berdasarkan rumusan masalah yang dibangun bagaimana meningkatkan kinerja bisnis UMKM Handy Crab kota Semarang melalui modal social dan modal manusia dengan kebijakan pemerintah sebabai moderating maka dapat disimpulkan bila kebijakan pemerintah yang berkaitan dengan UKM tepat sasaran dan sesuai dengan akar masalah UKM handy crab di kota Semarang, maka akan mendukung atau memperkuat peningkatan modal sosial dan modal manusia yang dimiliki UKM handy crab kota Semarang. 


\section{Kesimpulan hipotesis adalah sebagai berikut:}

1. Modal sosial berpengaruh positif dan signifikan terhadap kinerja bisnis UKM handy crab di Kota Semarang.

2. Modal manusia berpengaruh positif dan signifikan terhadap kinerja bisnis UKM handy crab di kota Semarang.

3. Kebijakan pemerintah memoderasi modal sosial terhadap peningkatan kinerja bisnis UKM handy crab kota Semarang.

4. Kebijakan pemerintah memoderasi modal manusia terhadap peningkatan kinerja bisnis UKM handy crab

\section{Implikasi Teoritis.}

1. Modal manusia berpengaruh positif dan signifikan terhadap kinerja bisnis UKM handy crab di kota Semarang.magnanya bila modal manusia yang dimiliki pengusahaUMKM handy crab ditingkatkan maka akan meningkatkan kinerja bisnis UKM handy crab di kota Semarang. Hal ini sesuai teori Pratisthita et al. (2014) Modal Sosial merupakan nilai-nilai, norma dan trust (rasa saling mempercayai) dalam suatu masyarakat dimana masyarakat saling berpartisipasidan terdapat proses timbal balik di dalamnya. Bourdieu (1986) menyatakan bahwa, volume social capital yang dimiliki oleh seseorang tergantung pada ukuran jejaring koneksi yang dapat dimobilisasikannya serta pada volume modal (ekonomi, budaya, atau simbolis) yang dimilikinya. Ini artinya bahwa, meski relatif tidak dapat direduksi ke modal ekonomi dan budaya yang dimiliki oleh agen tertentu, atau bahkan oleh seluruh agen yang terhubung, social capital tidak pernah independen seluruhnya dari agen karena pertukaran-pertukaran membentuk pengenalan satu sama lain. Penelitian Wahyuningrum (2013) yang menyimpulkan bahwa modal insani dan modal sosial memiliki pengaruh langsung terhadap kinerja pada UKM Kerajinan di Depok. Layla Khoirrini dan Lindawati Kartika (2014) menyatakan modal insani dan modal sosial berpengaruh positif dan signifikan terhadap kinerja. Penelitian Andriani juga menunjukkan bahwa modal sosial dapat meningkatkan kinerja (Andriani \& Zain, 2010).

2. Modal sosial nerpengaruh positif dan signifikan terhadap peningkatan kinerja bisnis UKM handy crab kota Semarang. Ini sesuai dengan peneliti Zuliyati dan Delima (2017) yang menyimpulkan bahwa intellectual capital mempunyai pengaruh positif dan signifikan terhadap kinerja UMKM. Wahyuningrum
(2013) yang menyimpulkan bahwa modal insani dan modal sosial memiliki pengaruh langsung terhadap kinerja pada UKM Kerajinan di Depok. Layla Khoirrini dan Lindawati Kartika (2014) menyatakan modal insani dan modal sosial berpengaruh positif dan signifikan terhadap kinerja,

3. Kebijakan pemerintah memoderasi modal sosial terhadap peningkatan kinerja bisnis handy crab kota Semarang.Hal ini sesuai Eka Nila Kencana (2018) menjelaskan peran pemerintah berpengaruh positif dan signifikan terhadap kinerja usaha pelaku usaha industri tenun di Kabupaten Jembrana.

4. Kebijakan pemerintah memoderasi modal manusia terhadap peningkatan kinerja bisnis UKM handy crab

\section{Implikasi Kebijakan.}

1. Pengusaha UKM Handy Crab kota Semarang mampu meningkatkan kinerja bisnis maka harus mampu kemampuan meningkatkan modal sosial yang dimiliki seperti menjaga kejujuran,meningkatkan hubungan yang baik kepada pemasok, konsumen/pelanggan, sesama pengusaha dan pemangku kepentingan serta meningkatkan jaringan bisnis.

2. Pengusaha UKM Handy Crabkota Semarang mampu meningkatkan kinerja bisnis maka semakin meningkatkan pendidikan (formal atau informal),ketrampilan,pengalaman dari para pengusaha sejenis serta menciptakan produk yang memiliki keunikan dan kreatif

3.Peran kebijakan pemerintah harus mampu memperkuat memberikan fasilitas yang mendukung, memberdayakan dalam klaster, memberikan tingkat suku bunga kredit murah, melakukan pembinaan dan regulasi yang melindungi UKM serta mendukung bersinergi dengan sektor lain seperti sektor pariwisata dan sektor pertanian sehingga dapat meningkatkan kinerja bisnis UKM handy crab di kota Semarang.

\section{DAFTAR PUSTAKA}

Abbasi, A., Hossain, L., \& Wigand, R. (2011). Social capital and individual performance: a study of academic collaboration. arXiv preprint arXiv: 1112.2460.

Aryee, S., Chay, Y. W., \& Tan, H. H. (1994). An examination of the antecedents of subjective career success among a managerial sample in Singapore. Human Relations, 47(5), 487-510.
Becker.GS.1993.Human Capital
Chicago

(US):University Chicago Press. 
Bontis, N., \& Serenko, A. (2009). A causal model of human capital antecedents and consequences in the financial service industry. Journal of Intellectual Capital, 10(1), 391-401.

Carmeli, A., \& Tishler, A. (2004a). The relationships between intangible organizational elements and organizational performance. Strategic management journal, 25, 1257-1278.

Carmeli, A., \& Tishler, A. (2004b). Resource, capabilities and the performance of industrial firms: A multivariate analysis. Managerial and Decision Economics, 25, 299-315.

Diva, Gede. 2009. Mengembangkan UMKM Melalui Pemberdayaan Peran Pemerintah Daerah. Jakarta: Bakrie School of Management.

Fukuyama,1999.Social Capital and Civil Society. The Institute of Public Policy. George Mason University. International Monetary Fund. hlm.104.

Grootaert, C., 1999, Social Capital, Household Welfare and Poverty in Indonesia, Local Level Institutions Study,,Social Development Department Environmentally and Socially Sustainable Development Network, The World Bank. Hair, J.F., Anderson, R.E., Tatham, R.L. \& Black, W.C., 1995. MulWorking Paper.No.3.World Bank.

Hartono, r., \& Soegianto, E. (2013). Analisis Pengaruh Modal Sosial dan Orientasi Kewirausahaan terhadap Kinerja Kewirausahaan pada PT. Mentar I Esa Cipta. Jakarta: Binus University

Hitt, M. A., Bierman, L., Shimizu, K., \& Kochhar, R. (2001). Direct and moderating effects of human capital on strategy and performance in professional service firms: A resource based perspective. Academy of Management Journal, 44(1), 13-28.

Hite, J.M,. and W.S.Hestery. 2001. "The Evolution of Firm Networks: From Emergence to Early Growth of the Firm". Strategic Management Journal 22,275-286.

ILO, 2010. Trend Ketenagakerjaan dan Sosial di Indonesia 2010. Mewujudkan Pertumbuhan Ekonomi dan Penciptaan Lapangan Kerja. Kantor ILO Indonesia

------, 2011. The ILO Convention on Domestic Workers:From the Shadows to the Light. UCL Labour Rights Institute On-Line Working Papers LRI WP $1 / 2011$

Khoirrin, L., \& Kartika, L. (2014). Pengaruh Modal
Insani dan Modal Sosial terhadap Kinerja (Studi Kasus Usaha Kecil dan Menengah (UKM) Makanan dan Minuman Kota Bogor). Jurnal Manajemen dan Organisasi .

Layla Khoirrini dan Lindawati Kartika .2013. Pengaruh Modal IInsani dan Modal Sosial terhadap Kinerja (Studi Kasus Usaha Kecil dan Menengah (UMKM) Makanan dan Minuman Kota Bogor).Jurnal Manajemen dan Organisasi.Vol V No.3.Desember 2014

Leana, Carrie R. And Frits K. Pil. 2006. Social Capital and Organizational Performance: Evidence from Urban Public Schools. Organization Science. Vol. 17 (3) , pp. $353-$ 366

Lechner, C dan Gudmundsson, SV. 2014. Entrepreneurial orientation, firm strategy and small firm performance. International Small Business Journal: Researching Entrepreneurship. Vol 32, Issue 1: 36-60

Mayo, A. 2000. The Role of Employee Development in The Growth of Intellectual

Capital. Personal Review, Vol. 29, No. 4.

Mathis, Robert L. dan John H. Jakson. 2003. Human Resource Management. South- Western Thomson Learning

Manning, Chris and Peter. Van Diermen (eds), 2000. Indonesia in Transition: Social Aspect of Reformasi and Crisis. Indonesia Assessment Series, Research School of Pacific and Asian Studies, Australia National University, Canberra. And Institute of Southeast Asian Studeis, Singapure.

Media Industri, 2011. Kebangkitan Industri Nasional. Media Industri. Media Menuju Kehidupan yang Lebih Baik. NO.1. Tahun 2011. Kementrian Perindustrian RI.

Munir, Fuady. (2010) Konsep Negara Demokrasi. Bandung, Refika Aditama

Oliveira, J. F. D. (2013). The influence of the social capital on business performance: an analysis in the context of horizontal business networks. RAM. Revista de Administração Mackenzie, 14(3), 209-235.

Rivai dan Basri. 2004."Manfaat Penilaian Kinerja"Jurnal kinerja-karyawandefinisi.html Sudibyo, Agustin Yvonne 2011

Siagian, Sondang. (1979) Administrasi Pembangunan. Jakarta, Gunung Agung.

Prasetiamartati, B., Fauzi, A., Dahuri, R., Fakhrudin, A., \& Lange, H. (2016). Modal Sosial dalam Pengelolaan Sumberdaya Perikanan. Jurnal Ilmu-Ilmu 
Perairan dan Perikanan Indonesia, 13(1), 7-19.

Pratisthita, R. N. (2014). Peran Modal Sosial dalam Menunjang Dinamika Kelompok Peternak Sapi Perah (Studi Kasus di Kelompok 3 TPK Pulosari Pangalengan). Jurnal Ilmu Ternak, 14(1).

Sanchez-Famoso, V., Akhter, N., Iturralde, T., Chirico, F., \& Maseda, A. (2015). Is nonfamily social capital also (or especially) important for family firm performance? human relations, 0018726714565724.

Shrestha, M.K. (2013) 'Internal versus External Social Capital and the Success of Community Initiatives: A Case of SelfOrganizing Collaborative Governance in Nepal', Public Administration Review, vol. 73, no. 1, January, pp. 154-164.

SMERU, 2002. Hubungan Industrial di Jabotabek, Bandung, dan Surabaya di Era Kebebasan Berserikat. Laporan Lembaga Penelitian SMERU dengan dukungan dari USAID/PEG.

Surin, E. F., Edward, O. T., Hussin, H. F., \& Wahab, I. A. (2017). Recognising the Importance of Strategic Business Network on Business Performance of SME Manufacturing Firm in Malaysia: Analysing The Moderating Influence of Human Capital and Business Environment. International Journal of Arts \& Sciences , 31-44.
Suci.R.P.2009.,Peningkatan Kinerja Melalui Orientasi Kewirausahaan, Kemampuan Manajemen dan Strategi bisnis (Studi Kasus pada Industri Kecil Menengah Bordir di Jawa Tengah.Jurnal Manajemen dan Kewirausahaan.Vol11.No.1.Hal 46-58

Tjokroamidjojo, Bintoro. (1985) Pengantar Administrasi Pembangunan. Jakarta, LP3ES.

Thatte, A. A. (2007). Competitive advantage of a firm through supply chain responsiveness and SCM practices. University of Toledo.

World Economic Forum, 2004. Global Competitiveness Report 2003/2004.

Wadji, M. F., \& Isa, M. (2014). Membangun Konsep Modal Manusia yang Berperanan dan Kinerja Pemasaran Industri Kecil. Research Method and Organizational Studies , 452-464

Wahyuningrum P. 2013. Model Peningkatan Kinerja Usaha Kecil dan Menengah (UMKM) Kluster Kerajinan Kota Depok melalui Modal Insani dan Modal Sosial [skripsi]. Bogor (ID): Institut Pertanian Bogor. Zula JK. 2006.

Wright, P. M., McMahan, G. C., \& McWilliams, A. (1994). Human resource and sustained competitive advantage: A resource-based perspective. International Journal of Human Resource Management, 5(2), 301-326.

Zulyati, dan Delima, Z.M. (2017).Intellectual Capital dan Kinerja UMKM. Jurnal PascaSarjana STIE Dharmaputra. Semarang (No 280-289) 